\title{
MELT RATE IMPROVEMENT FOR DWPF MB3: Crucible Studies (U)
}

\author{
T.H. Lorier
}

Westinghouse Savannah River Company Savannah River Technology Center Aiken, SC

TTP\#: SR-1-6-WT-31

TTR\#: HLW/DWPF/TTR-00-0044

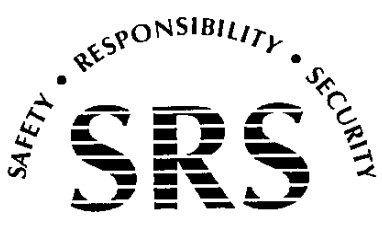

PREPARED FOR THE U.S. DEPARTMENT OF ENERGY UNDER CONTRACT NO. DE-AC09-96SR18500 
This document was prepared in conjunction with work accomplished under Contract No.

DE-AC09-96SR18500 with the U.S. Department of Energy.

\section{DISCLAIMER}

This report was prepared as an account of work sponsored by an agency of the United States Government. Neither the United States Government nor any agency thereof, nor any of their employees, makes any warranty, express or implied, or assumes any legal liability or responsibility for the accuracy, completeness, or usefulness of any information, apparatus, product or process disclosed, or represents that its use would not infringe privately owned rights. Reference herein to any specific commercial product, process or service by trade name, trademark, manufacturer, or otherwise does not necessarily constitute or imply its endorsement, recommendation, or favoring by the United States Government or any agency

thereof. The views and opinions of authors expressed herein do not necessarily state or reflect those of the United States Government or any agency thereof.

This report has been reproduced directly from the best available copy.

Available for sale to the public, in paper, from: U.S. Department of Commerce, National Technical Information Service, 5285 Port Royal Road, Springfield, VA 22161, phone: (800)

553-6847, fax: (703) 605-6900, email: orders@ntis.fedworld.gov online ordering: http://www.ntis.gov/ordering.htm

Available electronically at http://www.doe.gov/bridge

Available for a processing fee to U.S. Department of Energy and its contractors, in paper, from: U.S. Department of Energy, Office of Scientific and Technical Information, P.O. Box 62, Oak Ridge, TN 37831-0062, phone: (865 ) 576-8401, fax: (865) 576-5728, email: reports@ adonis.osti.gov 


\title{
MELT RATE IMPROVEMENT FOR DWPF MB3: Crucible Studies (U)
}

\author{
T.H. Lorier
}

Westinghouse Savannah River Company

Savannah River Technology Center

Aiken, SC

This report was prepared by Westinghouse Savannah River Company (WSRC) for the United States Department of Energy under Contract No. DE-AC09-96SR18500 and is an account of work performed under that contract. 


\begin{tabular}{|c|c|c|c|}
\hline Task Title: Improve Melt Rate & & $\begin{array}{l}\text { TTR Number: } \\
\text { HLW/DWPF/TTR- } \\
\text { 00-0044, Rev. } 0 \\
\end{array}$ & $\begin{array}{l}\text { TTR Date: } \\
10 / 24 / 00\end{array}$ \\
\hline $\begin{array}{l}\text { Task Leader: } \\
\text { T.H. Lorier } \\
\end{array}$ & Signature: & $\begin{array}{l}\text { Organization: } \\
\text { ITS }\end{array}$ & $\begin{array}{l}\text { Date: } \\
5 / 1 / 01\end{array}$ \\
\hline $\begin{array}{l}\text { Technical Reviewer: } \\
\text { David Peeler }\end{array}$ & Signature: and ledell & $\begin{array}{l}\text { Organization: } \\
\text { ITS }\end{array}$ & 51.101 \\
\hline $\begin{array}{l}\text { Reviewer: } \\
\text { Dan Lambert } \\
\end{array}$ & signature: $f l A$ & $\begin{array}{l}\text { Organization: } \\
\text { ITS }\end{array}$ & $\begin{array}{l}\text { Date: } \\
5 / 2 / 01 \\
\end{array}$ \\
\hline $\begin{array}{l}\text { Reviewer: } \\
\text { Douglas Witt } \\
\end{array}$ & Signatgreiflut & $\begin{array}{l}\text { Organization: } \\
\text { ITS }\end{array}$ & Dafe: 101 \\
\hline $\begin{array}{l}\text { Level } 3 \text { Manager: } \\
\text { E.W. Holtzscheiter } \\
\end{array}$ & Signaure; & $\begin{array}{l}\text { Organization: } \\
\text { ITS } \\
\end{array}$ & $\begin{array}{l}\text { Date: } \\
5 / 1 / 0 / \\
\end{array}$ \\
\hline $\begin{array}{l}\text { Level } 4 \text { Manager: } \\
\text { S.L. Marra } \\
\end{array}$ & $\begin{array}{l}\text { Signature: } \\
\text { Shavan L Maua }\end{array}$ & $\begin{array}{l}\text { Organization: } \\
\text { ITS }\end{array}$ & Date: $1 / 01$ \\
\hline
\end{tabular}


Immobilization Technology Section

Savannah River Technology Center

Rev. 0

Westinghouse Savannah River Company

\section{GLOSSARY}

DOE U.S. Department of Energy

DWPF Defense Waste Processing Facility

ITS Immobilization Technology Section

MB2 Macrobatch 2

MB3 Macrobatch 3

PNNL Pacific Northwest National Laboratory

QA Quality Assurance

SRAT Sludge Receipt Adjustment Tank

SRTC Savannah River Technology Center

TFA Tanks Focus Area

TIM Task Integration Manager 
Immobilization Technology Section

Savannah River Technology Center

Rev. 0

Westinghouse Savannah River Company

This page intentionally left blank. 


\section{ACKNOWLEDGMENTS}

The author would like to acknowledge Denny Bickford, Kevin Brown, Carol Jantzen, Dan Lambert, David Peeler, Mike Stone, Douglas Witt (SRTC), and Jim Sproull (WSRC) for their technical guidance and reviews; Irene Reamer, Phyllis Workman, Pat Toole, and Daniel Pittman for their patience and hard work; Curtis Sexton and Gary Dobos for glass-shop work; and William Holtzscheiter (TFA TIM for Immobilization) and Sharon Marra for management and guidance. This study was co-funded by the Department of Energy's Office of Science and Technology through the Tanks Focus Area and through the Defense Waste Processing Facility. Westinghouse Savannah River Company is operated for the U.S. Department of Energy under Contract No. DE-AC09-96SR18500. 


\section{Contents}

GLOSSARY

ACKNOWLEDGEMENTS. .vii

LIST OF FIGURES. .........................................................................

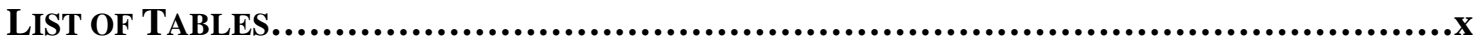

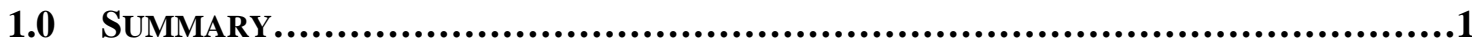

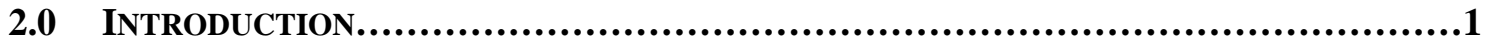

3.0 EXPERIMENTAL PROCEDURES..................................................

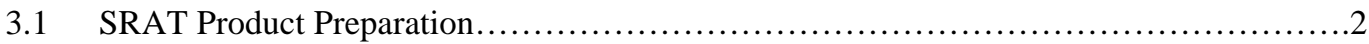

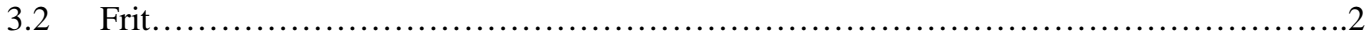

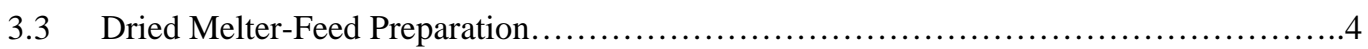

4.0 RESULTS AND DISCUSSION...............................................................5

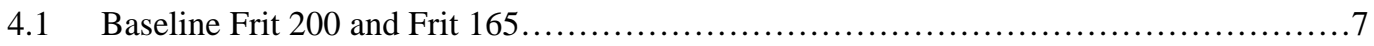

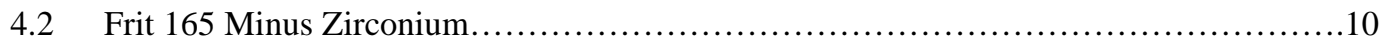

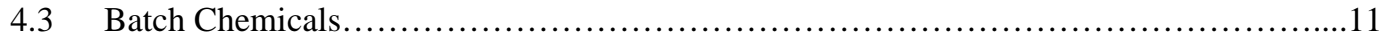

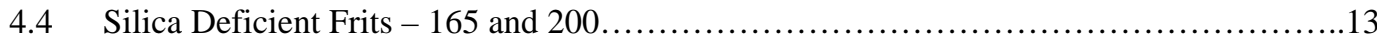

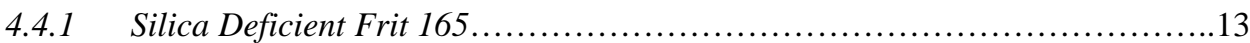

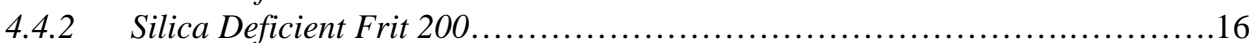

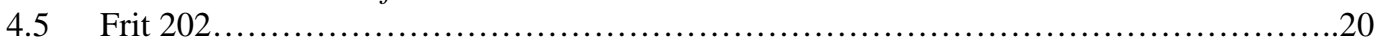

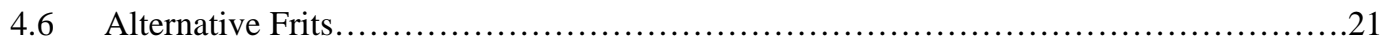

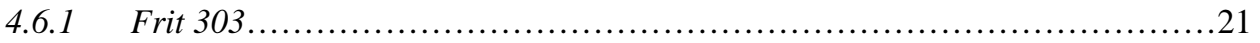

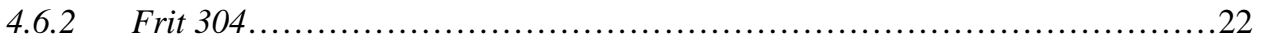

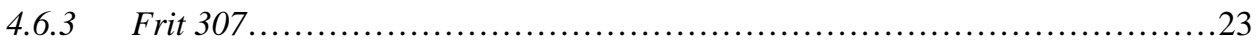

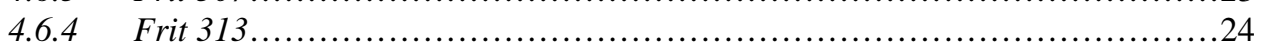

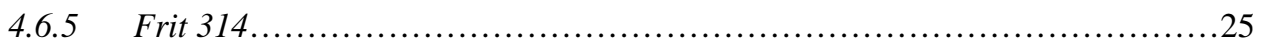

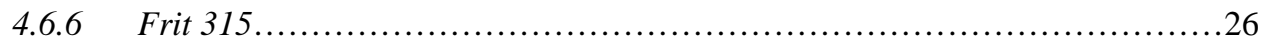

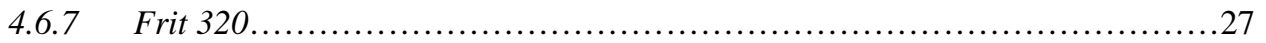

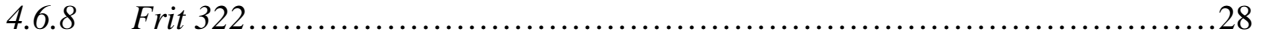

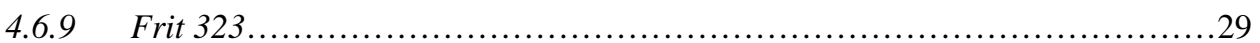

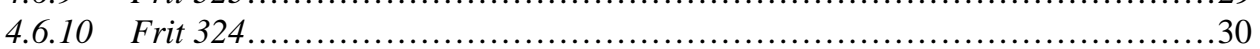

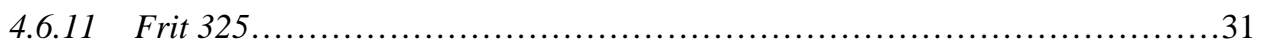

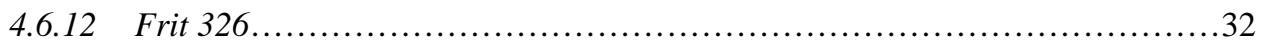

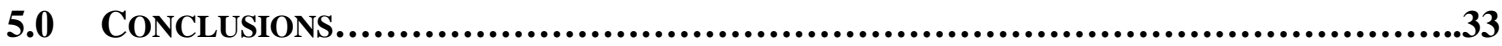

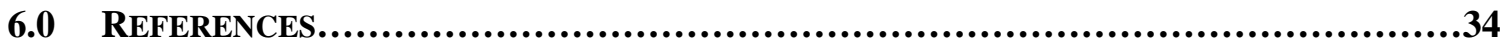

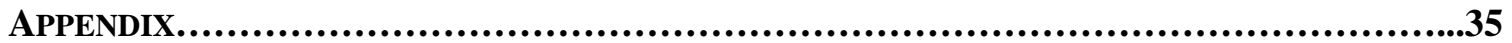




\section{LIST OF FigURES}

Figure 1. Representative samples of a) sintered mass, b) small bubbles, c) medium..........6 bubbles, d) large bubbles, and e) complete glass with no bubbles.

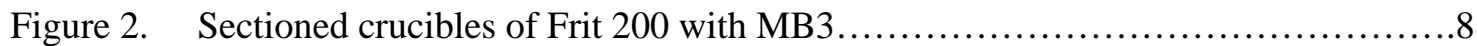

Figure 3. Sectioned crucibles of Frit 165 with MB3 .................................

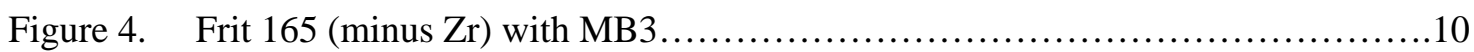

Figure 5. Frit 165 (Batch chemicals) with MB3 .....................................11

Figure 6. Frit 200 (Batch chemicals) with MB3 ....................................

Figure 7. Frit 165 (25\% silica deficiency) with MB3 .............................. 14

Figure 8. Frit 165 (50\% silica deficiency) with MB3 ............................... 15

Figure 9. Frit 165 (75\% silica deficiency) with MB3 .............................. 16

Figure 10. Frit 200 (25\% silica deficiency) with MB3 .............................. 17

Figure 11. Frit 200 (50\% silica deficiency) with MB3 ............................. 18

Figure 12. Frit 200 (75\% silica deficiency) with MB3............................... 19

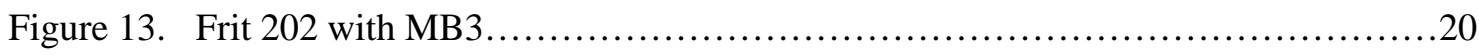

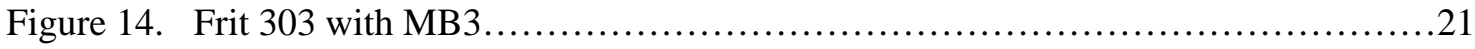

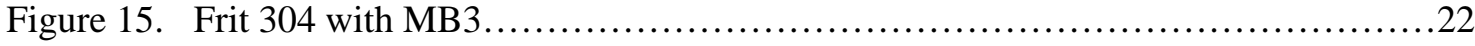

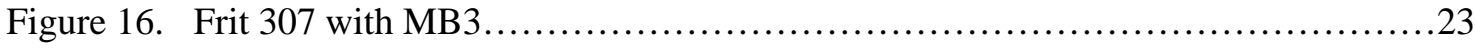

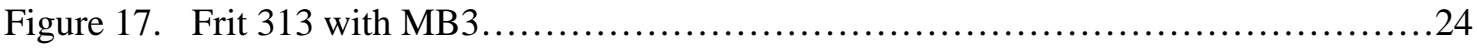

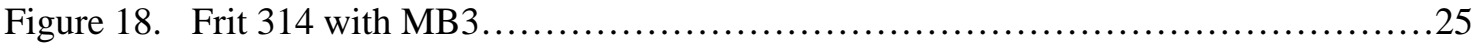

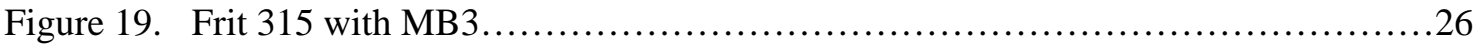

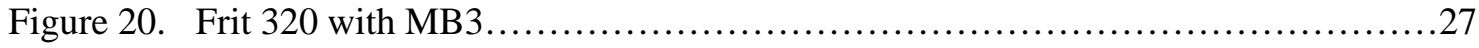

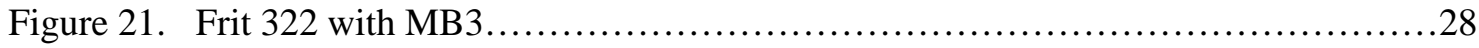

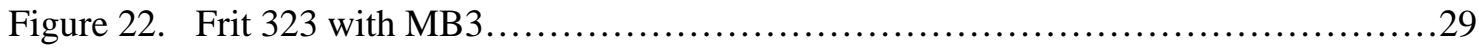

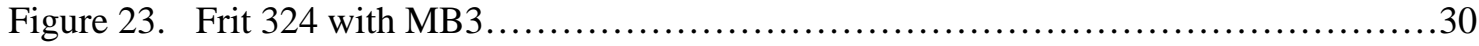

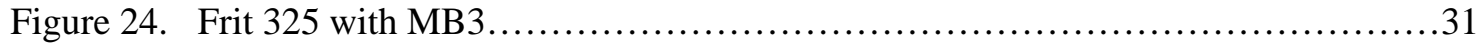

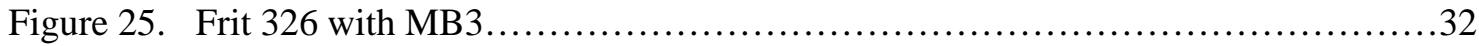


Immobilization Technology Section

Savannah River Technology Center

Rev. 0

Westinghouse Savannah River Company

\section{LIST OF TABLES}

Table I. Frit compositions (in mass percent) of baseline frits....................... 3

Table II. Frit compositions (in mass percent) of alternative frits developed by.............3 SRTC and PNNL.

Table III. Summarization of Crucible Tests of Frits 165, 200, and 303-326 with MB3.....36

Table IV. Foam Summarization of Frits 165, 200, and 303-326 with MB3...............38 
Immobilization Technology Section

Savannah River Technology Center

Rev. 0

Westinghouse Savannah River Company

This page intentionally left blank. 


\subsection{Summary}

The objective of this research is to evaluate the melting behavior of Macrobatch 3 (MB3) for the Defense Waste Processing Facility (DWPF). This study focuses on the manipulation of the frit composition in order to enhance the melting rate of MB3, without sacrificing the quality of the final glass form. Formation of a foam layer prevents incoming feed material from converting into a homogeneous liquid melt efficiently (i.e., lowering melt rate or throughput), thus resulting in slower canister production by DWPF over a given time period. The goal is to find the proper frit composition so the development of this insulating layer is averted. Peeler et al. (2001) outline further incentives of this research.

Because of the multiple phenomena occurring at the same time during the melting process, several analytical techniques should be utilized in order to comprehend the mechanisms leading to a low melt rate. This study was performed on a "small scale" by using $100 \mathrm{~mL}$ alumina crucibles to evaluate the batch-to-glass conversion process and melt rate of MB3 with existing and alternative frits. The basic understanding of the reaction pathways and melting behavior at this level will then be applied to such larger scale processes as the melt-rate furnace, slurry-fed mini-melter, and the melter in DWPF. Most of the technical issues behind this understanding are discussed by Peeler et al. (2001).

\subsection{Introduction}

The definition of melt rate in this case is the rate of the batch-to-glass process (i.e., how quickly feed materials are converted to a liquid melt). In an attempt to increase DWPF's rate of production during the MB3 campaign ( 50/50 blend of Tank 8 and Tank 40), tests were conducted to determine the potential for increasing melt rate by changing the glass former and/or feed preparation process. Control over the composition of the incoming batch (specifically the composition of the glass former) may adjust reaction pathways within the cold cap in such a way that enhances melt rate and increases melter efficiency. If successful, higher production goals may be met without sacrificing the quality of the final waste (glass) form. 


\subsection{Experimental Procedures}

A series of crucible tests was conducted by mixing 24 different frits separately with a Macrobatch 3 sludge simulant. The approach for the testing design was reported by Stone and Lambert (2000). Subsections 3.1 through 3.3 highlight the sludge fabrication and receipt, production of frit, and mixing and drying techniques.

During the performance of this task, all equipment was controlled in accordance with the Quality Assurance (QA) program identified in the Immobilization Technology Section (ITS) QA Program Description, SRT-PTD-98-0003, Rev. 3, dated 3/5/01. This program implements and complies with the requirements of the WSRC QA Manual, 1Q, QAP 12-1, Control of Measuring and Test Equipment requirements. The QA requirements of RW-0333P do not apply to this task, but any mini-melter runs would have to meet those requirements (HLW/DWPF/TTR-00-0044).

\subsection{SRAT Product Preparation}

Instructions for the preparation of MB3 Sludge Receipt Adjustment Tank (SRAT) product for melt rate tests was outlined by Stone (SRT-PTD-2000-00082). Preparation of all SRAT product was conducted at TNX and then delivered to the Savannah River Technology Center (SRTC) for crucible testing (see Stone et al. (2001) for more details). However, every SRAT batch was somewhat different due to variances in water content, thereby causing each batch to have different "calcine factors." This factor dictates how much SRAT product is added to a specified amount of frit for each crucible test. The "calcine factor" of the SRAT product is determined by heating the SRAT product slurry to $900^{\circ} \mathrm{C}$ and then determining the percentage of SRAT solids remaining. Calcine factors of the different sludge batches received are documented in the appropriate notebook (WSRC-NB-2000-00144).

\section{2 $\quad$ Frit}

Of the 24 frits tested, three were prefabricated offsite, while the rest were made at SRTC (see WSRC-TR-2001-00152 for more details). The prefabricated frits were Frit 165, 200, and 202 (Lot \#'s AX667974 canisters 3 \& 4, CS, and CN, respectively). Stone and Lambert (2000) discuss the use of these frits for an evaluation of MB2 melt rate. These frits were also used to evaluate melt behavior/rate for MB3. The compositions of these frits are listed in Table I, and the alternative frit compositions (see Peeler et al. 2001) are shown in Table II. 
Table I. Frit compositions of baseline frits.

\begin{tabular}{lcccc}
\hline Frit ID & Frit 165 & Frit 200 & $\begin{array}{c}\text { Frit 165 } \\
\text { (minus Zr)* }\end{array}$ & Frit 202 \\
\hline $\mathrm{Al}_{2} \mathrm{O}_{3}$ & 0.00 & 0.00 & 0.00 & 0.00 \\
$\mathrm{~B}_{2} \mathrm{O}_{3}$ & 10.00 & 12.00 & 10.10 & 8.00 \\
$\mathrm{Li}_{2} \mathrm{O}$ & 7.00 & 5.00 & 7.07 & 7.00 \\
$\mathrm{Na}_{2} \mathrm{O}$ & 13.00 & 11.00 & 13.13 & 6.00 \\
$\mathrm{SiO}_{2}$ & 68.00 & 70.00 & 68.69 & 77.00 \\
$\mathrm{ZrO}_{2}$ & 1.00 & 0.00 & 0.00 & 0.00 \\
$\mathrm{MgO}$ & 1.00 & 2.00 & 1.01 & 2.00 \\
\hline
\end{tabular}

* See Section 4.2 for explanation.

Table II. Frit compositions (in mass percent) of alternative frits ${ }^{\mathrm{a}}$ developed by SRTC and PNNL.

\begin{tabular}{lcccccccccccc}
\hline Frit ID & Frit & Frit & Frit & Frit & Frit & Frit & Frit & Frit & Frit & Frit & Frit & Frit \\
& 303 & 304 & 307 & 313 & 314 & 315 & 320 & 322 & 323 & 324 & $325^{\mathrm{b}}$ & 326 \\
\hline $\mathrm{Al}_{2} \mathrm{O}_{3}$ & 2.29 & 2.29 & 0.00 & 0.00 & 0.00 & 0.00 & 0.00 & 0.00 & 0.00 & 0.00 & 0.00 & 0.00 \\
$\mathrm{~B}_{2} \mathrm{O}_{3}$ & 20.13 & 6.71 & 12.08 & 6.71 & 20.13 & 20.13 & 8.00 & 8.00 & 15.00 & 15.00 & 8.55 & 8.00 \\
$\mathrm{Li}_{2} \mathrm{O}$ & 10.12 & 5.80 & 10.74 & 10.74 & 5.94 & 10.03 & 8.00 & 5.00 & 5.19 & 8.28 & 7.55 & 8.00 \\
$\mathrm{Na}_{2} \mathrm{O}$ & 0.00 & 18.07 & 4.67 & 8.75 & 6.12 & 0.00 & 12.00 & 10.00 & 8.28 & 5.19 & 9.10 & 11.00 \\
$\mathrm{SiO}_{2}$ & 67.46 & 67.13 & 72.51 & 73.80 & 65.79 & 69.84 & 72.00 & 77.00 & 71.53 & 71.53 & 72.80 & 72.00 \\
$\mathrm{ZrO}_{2}$ & 0.00 & 0.00 & 0.00 & 0.00 & 2.01 & 0.00 & 0.00 & 0.00 & 0.00 & 0.00 & 0.50 & 0.00 \\
$\mathrm{MgO}$ & 0.00 & 0.00 & 0.00 & 0.00 & 0.00 & 0.00 & 0.00 & 0.00 & 0.00 & 0.00 & 1.50 & 1.00 \\
\hline
\end{tabular}

${ }^{a}$ See Section 4.6 for more details.

${ }^{\mathrm{b}}$ Testing with Frit 325 was conducted as a 50/50 blend with Frit 202 when mixed with Macrobatch 3 simulant. The composition listed for Frit 325 is for this 50/50 combination.

To fabricate frits at SRTC, the chemicals were batched to target a specified composition and amount of frit, inserted in the furnace set at $1150^{\circ} \mathrm{C}$, held at temperature for approximately one hour, and then poured onto a stainless-steel plate and quenched in air (WSRC-TR-2001-00152) ${ }^{1}$.

Once the final melting was complete, the frit was ground and sieved to a particle size of $-80,+200$ mesh. Recovery of this correct particle size was approximately 50\% (i.e., had to make $500 \mathrm{~g}$ of glass to acquire $\sim 250 \mathrm{~g}$ of the desired size fraction). It was this $-80,+200$ mesh-sized frit that was then mixed with the sludge simulant for each crucible test. 


\subsection{Dried Melter-Feed Preparation}

Batching for the crucible tests was based on producing approximately 45 grams of glass and a $23.2 \%$ waste loading on an oxide basis. The required amounts of frit and sludge were combined in a $125 \mathrm{~mL}$ polyethylene bottle, shaken to ensure complete mixing, and then poured into a 100 $\mathrm{mL}$ alumina crucible. Approximately $5 \mathrm{~mL}$ of water was used to rinse the polyethylene bottle in order to transfer as much product as possible into each crucible. Each crucible was then covered with an alumina lid and the total, pre-drying weight was recorded.

The crucibles were then inserted without lids into a vacuum oven for drying. The vacuum oven had a setpoint of $70^{\circ} \mathrm{C}$ (according to GTOP-3-046, Rev.4) with a vacuum of approximately $24 \mathrm{in}$. $\mathrm{Hg}$ pulled on the system, in order to remove as much water as possible from each crucible. Each crucible remained in the vacuum oven under these conditions for at least 18 hours, and sometimes longer, the basis of which was determined by the consistency of the contents. If the sample contained too much liquid, then it was inserted back into the vacuum oven for further drying. If the contents were dry enough (tackiness of peanut butter or drier), then they were removed from the oven and were ready for firing. The original protocol (as defined by SRT-PTD-2000-00088, Rev. 1) called for the sample to be dried to a net weight of 72 grams or less. No water was added back to any crucible after drying. Once drying was complete, the weight of the crucible with the lid was recorded again before insertion into the furnace.

Due to a problem that occurred when placing crucibles that still contained too much water in the furnace at temperature, drying at a temperature higher than $70^{\circ} \mathrm{C}$ was investigated. It was suggested to dry at $150^{\circ} \mathrm{C}$, but there was an issue of whether or not too many formates would be volatilized from the sample at that temperature, thereby altering the redox. Also, it was found that at approximately $80^{\circ} \mathrm{C}$, the contents of the crucible began to boil when under a vacuum. This caused splatter in the oven, thus invalidating the runs. Therefore, it was decided to continue drying at $70^{\circ} \mathrm{C}$, but for longer time periods, in order to remove as much water as possible.

Prior to being inserted in the furnace, any material above the top of the batch was scraped from the crucible walls and the original batch height was marked with a high-temperature pen on the outside of each crucible to provide a measure of relative foam height and batch expansion. The

\footnotetext{
${ }^{1}$ Further documentation of the fabrication of frits at SRTC can be found in WSRC-NB-2000-00144.
} 
ready crucibles were then placed in a secondary (kyanite) crucible and preheated at $70^{\circ} \mathrm{C}$ for at least 30 minutes to prevent thermal shock (according to GTOP-3-046, Rev. 4). The crucible tests were conducted over a temperature range of $700^{\circ} \mathrm{C}$ to $900^{\circ} \mathrm{C}$ in $50^{\circ}$ intervals ${ }^{2}$. The charged and covered crucibles were inserted at temperature and held for two hours. After two hours, the crucibles were removed and air-quenched. Once cooled, the weight of the crucible with lid was measured, and then the crucible was cross-sectioned for visual analysis.

\subsection{Results and Discussion}

More than 175 crucible tests were conducted in the MB3 melt rate study. These small-scale tests were used to provide a basic understanding of the melting processes and behavior of MB3 feed and supplied the basis for interpretation of larger scaled tests. In the following subsections, comparisons of baseline Frit 200 and Frit 165, silica-deficient frits, Frit 202, and alternative frits developed via a joint Pacific Northwest National Laboratory (PNNL) and SRTC effort (Peeler et al. 2001) are made.

It must be noted that all crucible tests performed for this study were done on a single-analysis basis. Due to time and budget constraints, no duplicates for MB3 with any frit were done. However, reproducibility of the results of these tests is assumed. Also, the results of the crucible tests do not give a specific "melt rate," but hopefully will provide insight into the melt behavior of MB3 and be part of the foundation on which a frit selection can be made. The crucible studies are part of a suite of tests discussed by Peeler et al. (2001).

In Figure 1, representative examples of the terminology used in this section to describe the subjective reaction pathways are shown. Figure 1a) depicts a typical sintered mass, where the particles have fused together with no evidence of a liquid phase forming. Figures 1b), 1c), and 1d) represent typical melts containing small, medium, and large-sized bubbles, respectively, and 1e) represents a typical glass with no bubbles.

\footnotetext{
${ }^{2}$ Initially it was decided to perform the crucible tests over a temperature range of $600^{\circ} \mathrm{C}$ to $1000^{\circ} \mathrm{C}$ in $50^{\circ}$ intervals. However, it was discovered that the batches were not melted enough at temperatures below $700^{\circ} \mathrm{C}$, and nothing new was seen at temperatures greater than $900^{\circ} \mathrm{C}$. So, the remainder of the tests was limited to the $700^{\circ} \mathrm{C}$ to $900^{\circ} \mathrm{C}$ range, and any other data at different temperatures outside of this range were not mentioned in the results.
} 

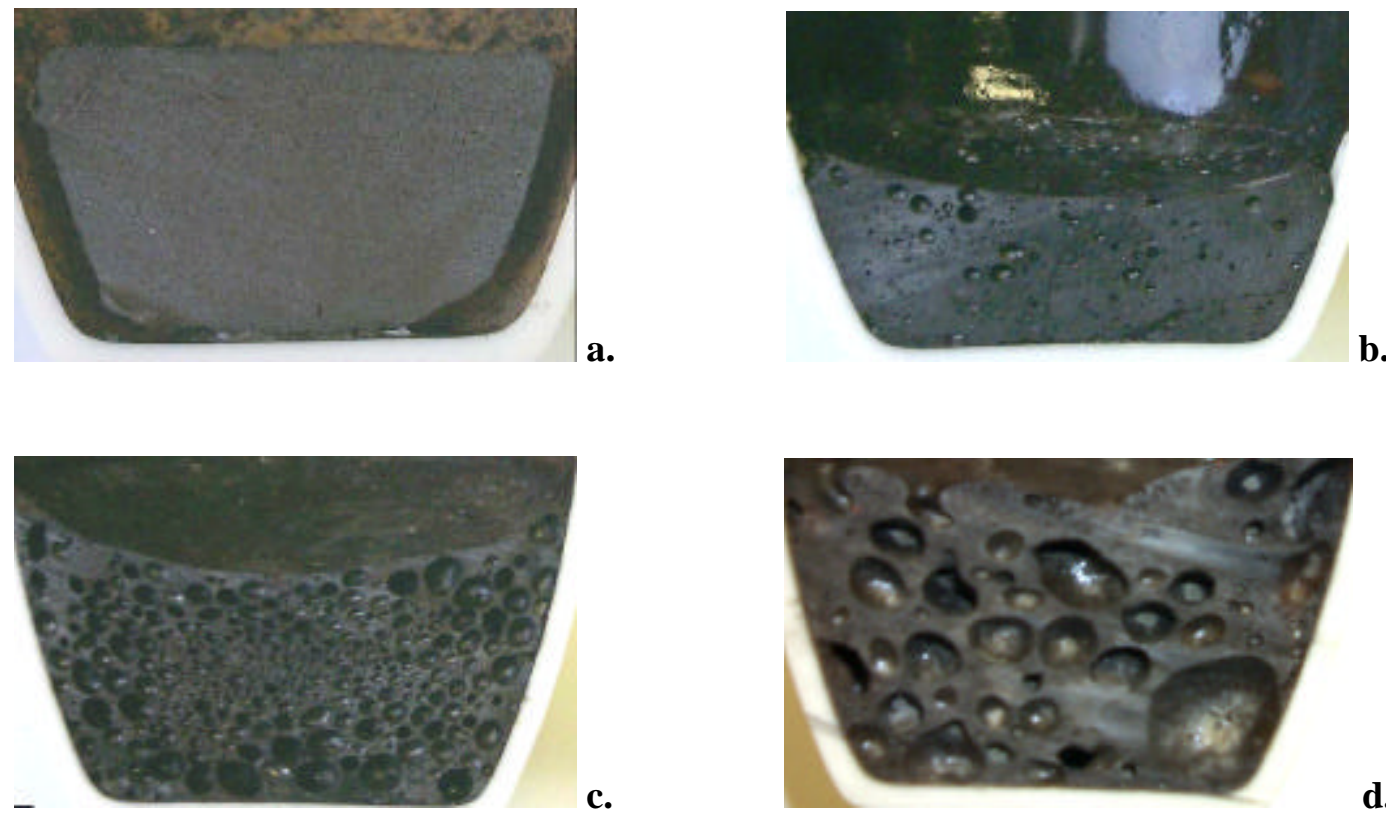

c.

d.

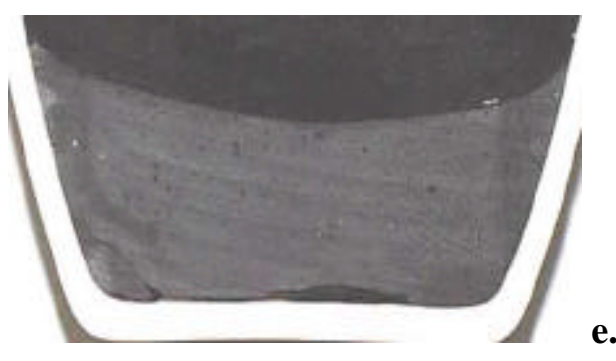

Figure 1. Representative samples of a) sintered mass, b) small bubbles, c) medium bubbles, d) large bubbles, and e) complete glass with no bubbles.

The accumulation of bubbles in the melt could increase foam potential, but does not indicate the level of stability for that foam. Figure 1b) shows how bubbles begin to accumulate in a melt, whereas Figures 1c) and 1d) show foam (larger bubble accumulation with some batch expansion). Batch expansion in these tests does not mean expansion of the melt past the initial batch mark on the outside of the crucible. Upon insertion into the furnace and initial heating, the batch contracted, reached a certain level, and then expanded again with the formation of foam. 


\subsection{Baseline Frit 200 and Frit 165}

Current processing in DWPF of MB2 (Tank 42) utilizes Frit 200. However, Stone and Lambert (2000) concluded that Frit 165 would improve the melt rate of MB2. Given that Frit 200 is the current baseline frit and Frit 165 was shown to improve melt rate for MB2, it seemed logical to begin the assessment of the melting behavior of MB3 with these two frits. Variations of these frits, such as silica deficient Frits 165 and $200^{3}$, Frit 165 minus zirconium, and Frits 165 and 200 using batch chemicals, were also tried and will be discussed in later subsections.

The first baseline frit tested in crucibles with MB3 was Frit 200, and cross-sections are shown in Figure 2. At $700^{\circ} \mathrm{C}$, the sample just began to melt and a few tiny bubbles began to form. At $750^{\circ} \mathrm{C}$, the batch expanded slightly and the size and quantity of the bubbles began to increase. The temperature at which foaming was the worst was $800^{\circ} \mathrm{C}$ for Frit 200 , where large bubbles formed throughout the melt. As the temperature increased to $850^{\circ} \mathrm{C}$ though, only small residual bubbles remained mostly close to the top of the melt, while very few, tiny bubbles persisted in the glass at $900^{\circ} \mathrm{C}$.

\footnotetext{
${ }^{3}$ The use of a "silica deficient" Frit 165 or 200 will result in the same targeted glass composition as the existing frits. The only difference is the point at which the $\mathrm{SiO}_{2}$ is added to the mix. With silica deficient frits, a portion of the $\mathrm{SiO}_{2}$ was left out of the frit during batching and melting, and then added separately later. See Subsection 4.4 for further explanation.
} 


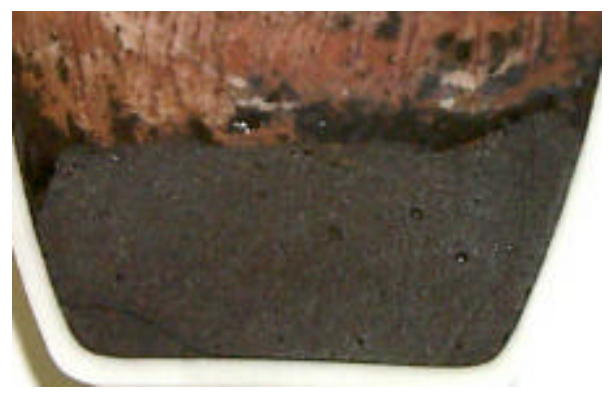

$700^{\circ} \mathrm{C}$
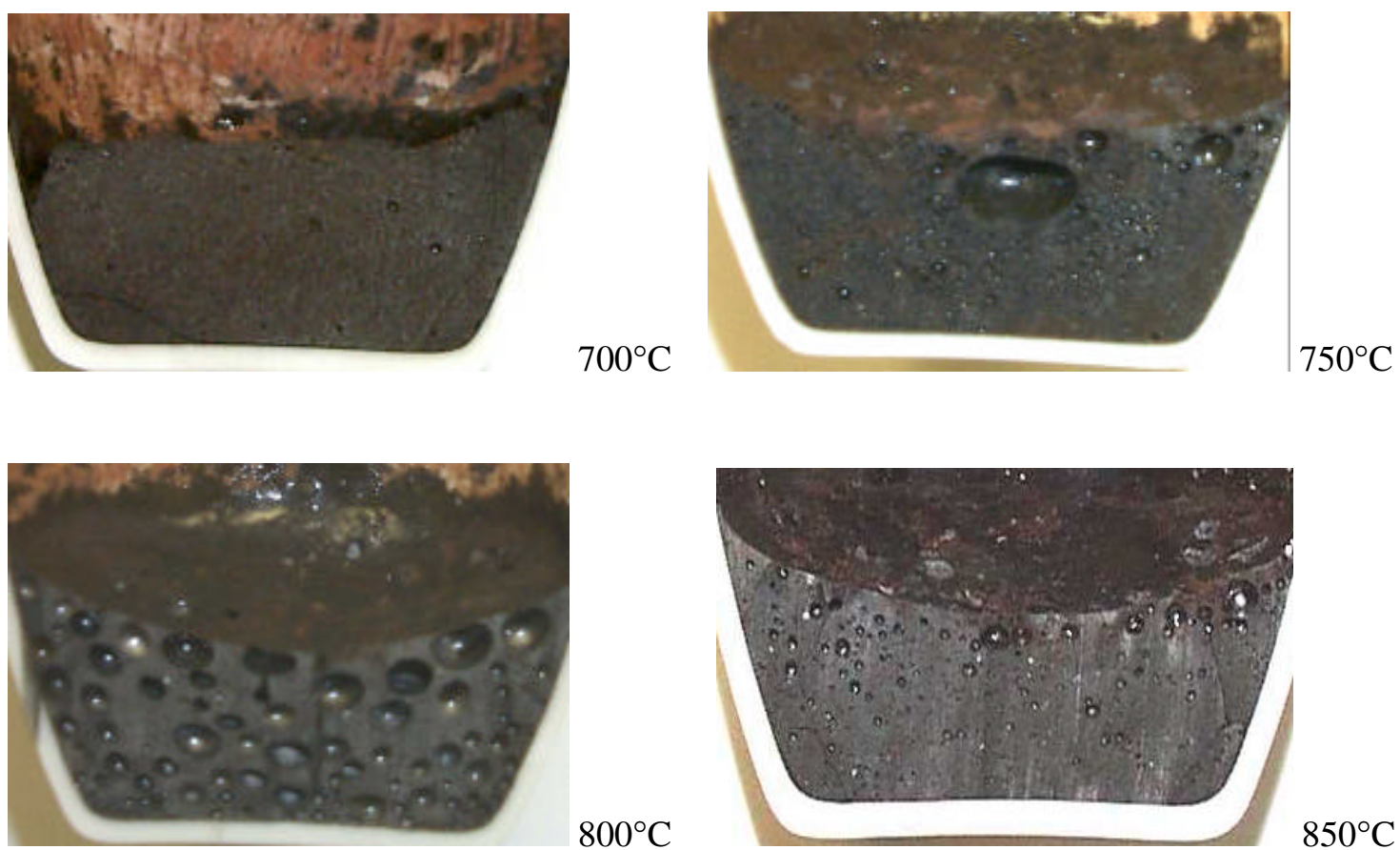

$850^{\circ} \mathrm{C}$

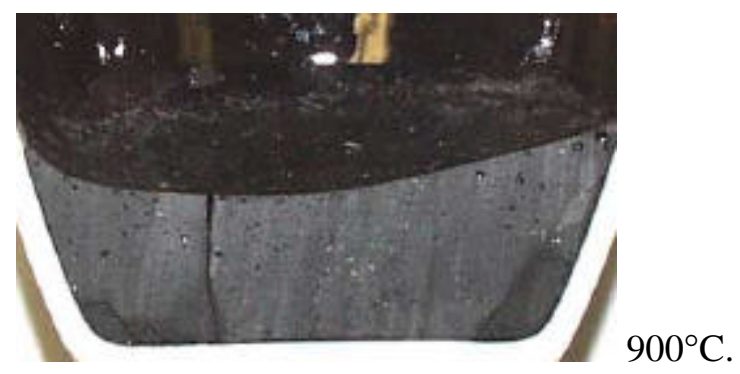

Figure 2. Sectioned crucibles of Frit 200 with MB3.

Frit 165 is represented in Figure 3. A basic sintered mass with a few bubbles just beginning to form at the initial melt occurs for Frit 165 at $700^{\circ} \mathrm{C}$. The foam problem was the worst (greatest batch expansion) at $750^{\circ} \mathrm{C}$ though, with many medium-to-large sized bubbles present throughout the melt. At $800^{\circ} \mathrm{C}$, most of the foam dissipated to where only small residual bubbles remained. By $850^{\circ} \mathrm{C}$, and especially $900^{\circ} \mathrm{C}$, the melt was completely glass with few or no bubbles remaining. 

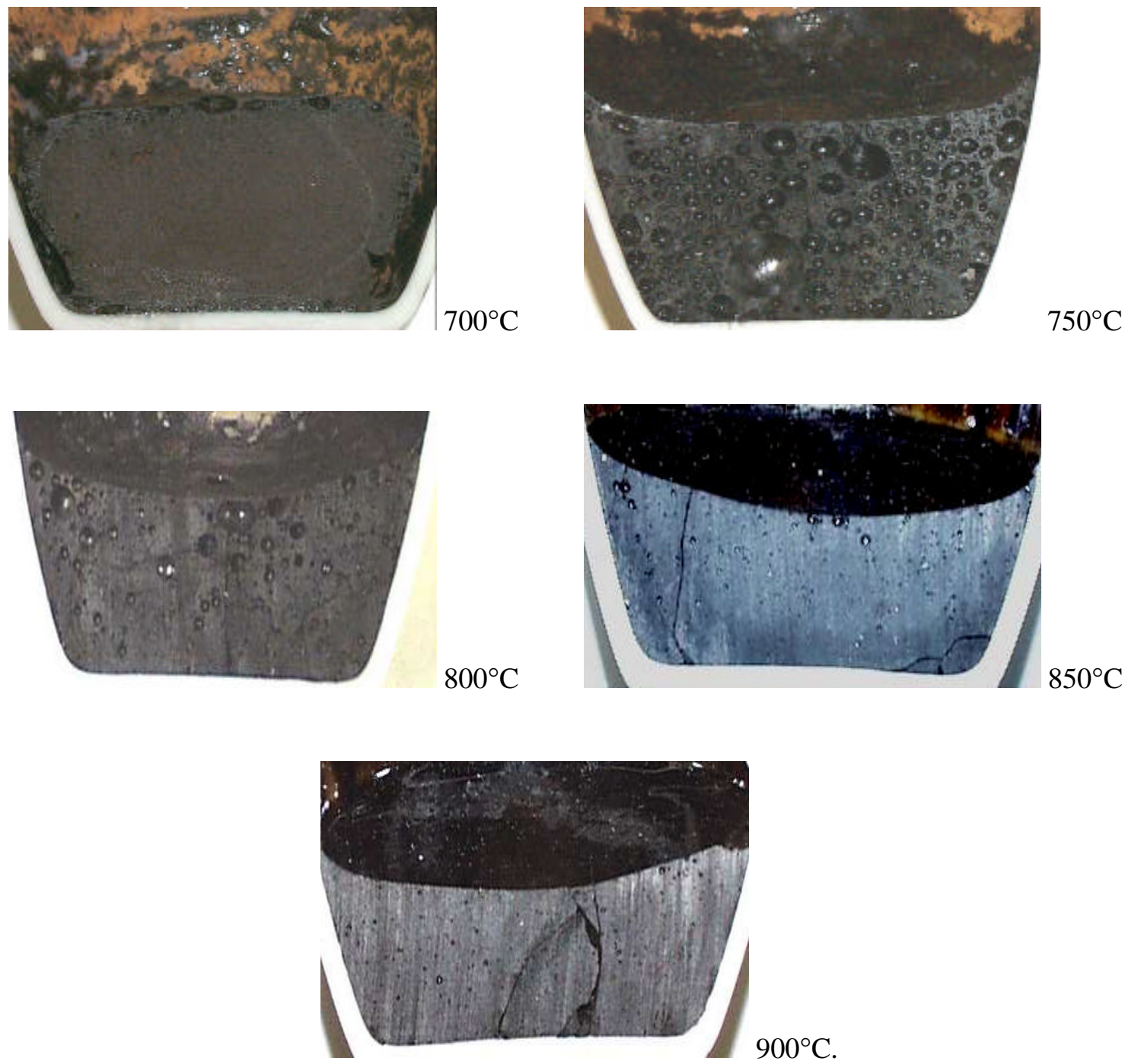

Figure 3. Sectioned crucibles of Frit 165 with MB3.

As evidenced by Figures 2 and 3, the main difference between these two existing frits is the temperature at which foaming was the worst. For Frit 200, the most and largest bubbles arise at $800^{\circ} \mathrm{C}$, while it is $750^{\circ} \mathrm{C}$ for Frit 165 . Only subtle contrasts were seen at other temperatures, so it is deemed that the melting behavior of MB3 is virtually the same when mixed with either Frit 200 or Frit 165, based on the crucible tests. A summary of what occurred for Frits 165 and 200 is shown in Appendix A. 


\subsection{Frit 165 minus Zirconium}

Frit 165 contains 1 mass $\% \mathrm{ZrO}_{2}$ for the stated purposes of increased durability. Based on a request from DWPF however, Frit 165 was "redesigned" without $\mathrm{ZrO}_{2}$ (all other components renormalized (see Table I)) to distinguish if any variations in melt behavior or melt rate could be detected. Frit 165 without $\mathrm{ZrO}_{2}$ may relieve burdensome documentation given that the current reporting documents do not include $\mathrm{ZrO}_{2}$. Figure 4 shows the results of the Frit 165 without $\mathrm{ZrO}_{2}$ crucible tests.

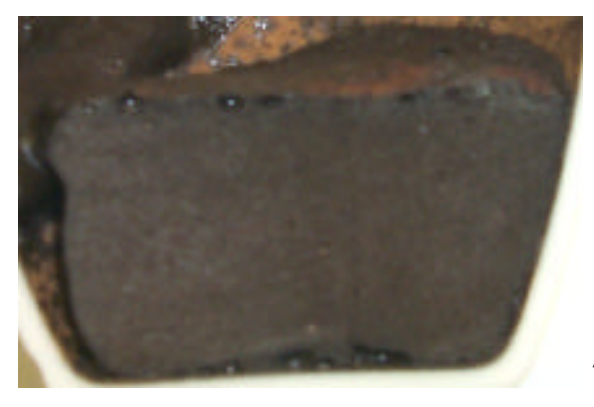

$700^{\circ} \mathrm{C}$
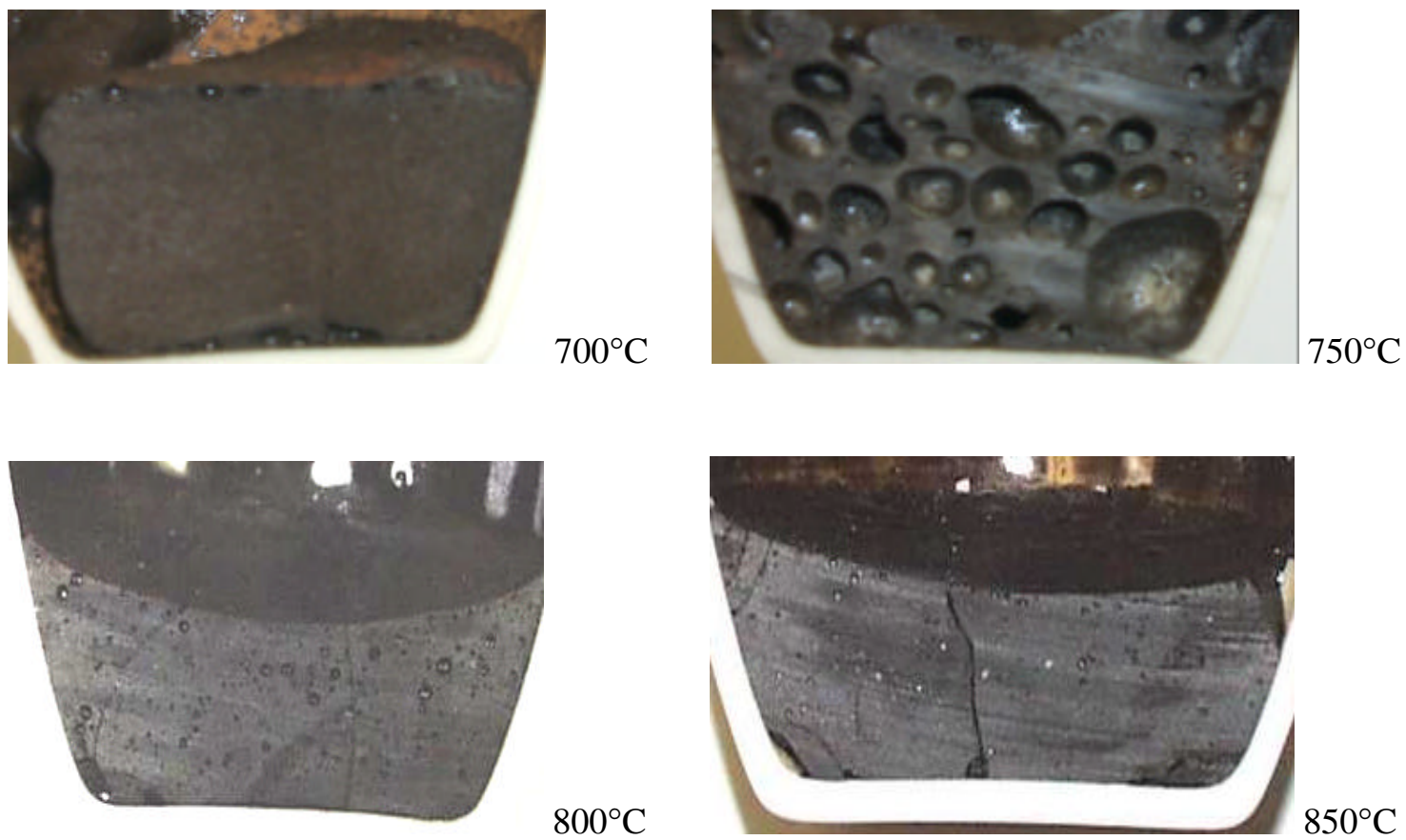

$800^{\circ} \mathrm{C}$
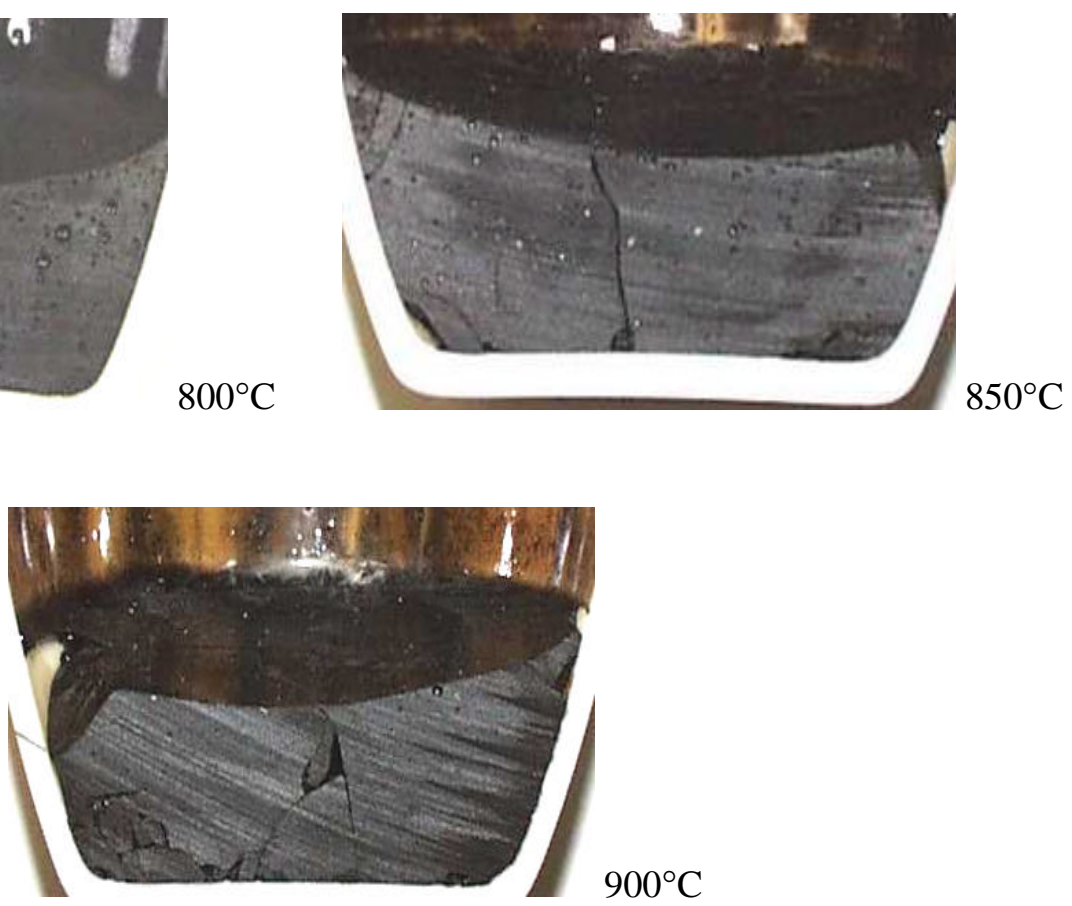

Figure 4. Frit 165 (minus Zr) with MB3. 
Clearly the temperature at which foam is the worst for this frit is $750^{\circ} \mathrm{C}$. Based on this single analysis, the potential for foam is higher than that of Frits 165 or 200 . However, once $800^{\circ} \mathrm{C}$ is reached in this case, very few bubbles remain and a complete glass is formed, based on the series of isothermal tests. It appears that removing the zirconium from Frit 165 does not impact the melting behavior of MB3 versus the original Frit 165 .

\subsection{Batch chemicals}

In Section 4.2, the melting behaviors of pre-fabricated Frit 165 and Frit 200 coupled with MB3 were assessed via the isothermal crucible tests. It was decided though to assess the potential impact of using batch chemicals (compositionally the same as the prefabricated frits) - combine all individual components (listed in Table I) of the frit separately. The results of Frit 165 (batch chemicals) and Frit 200 (batch chemicals) are shown in Figures 5 and 6, respectively.
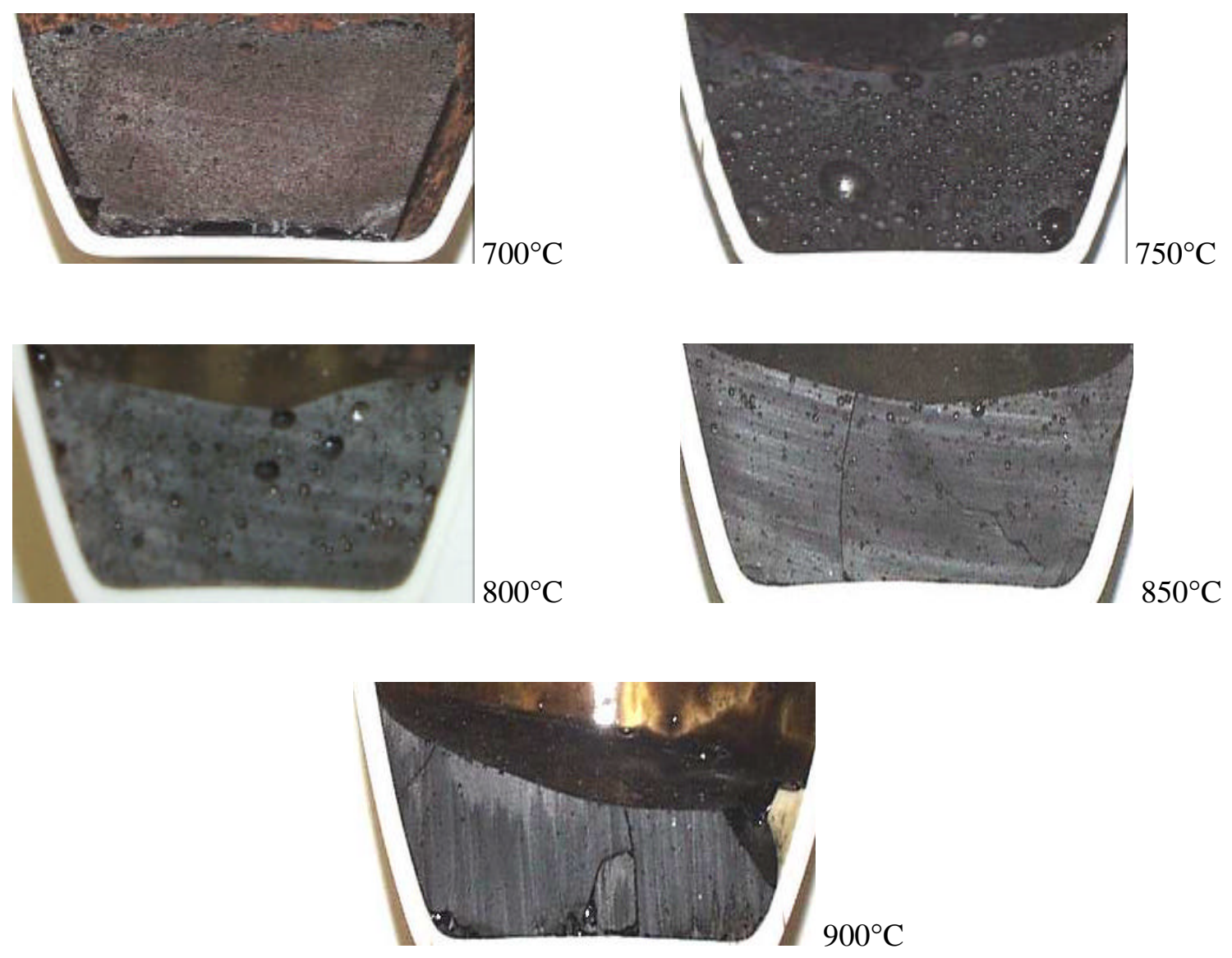

Figure 5. Frit 165 (Batch chemicals) with MB3. 

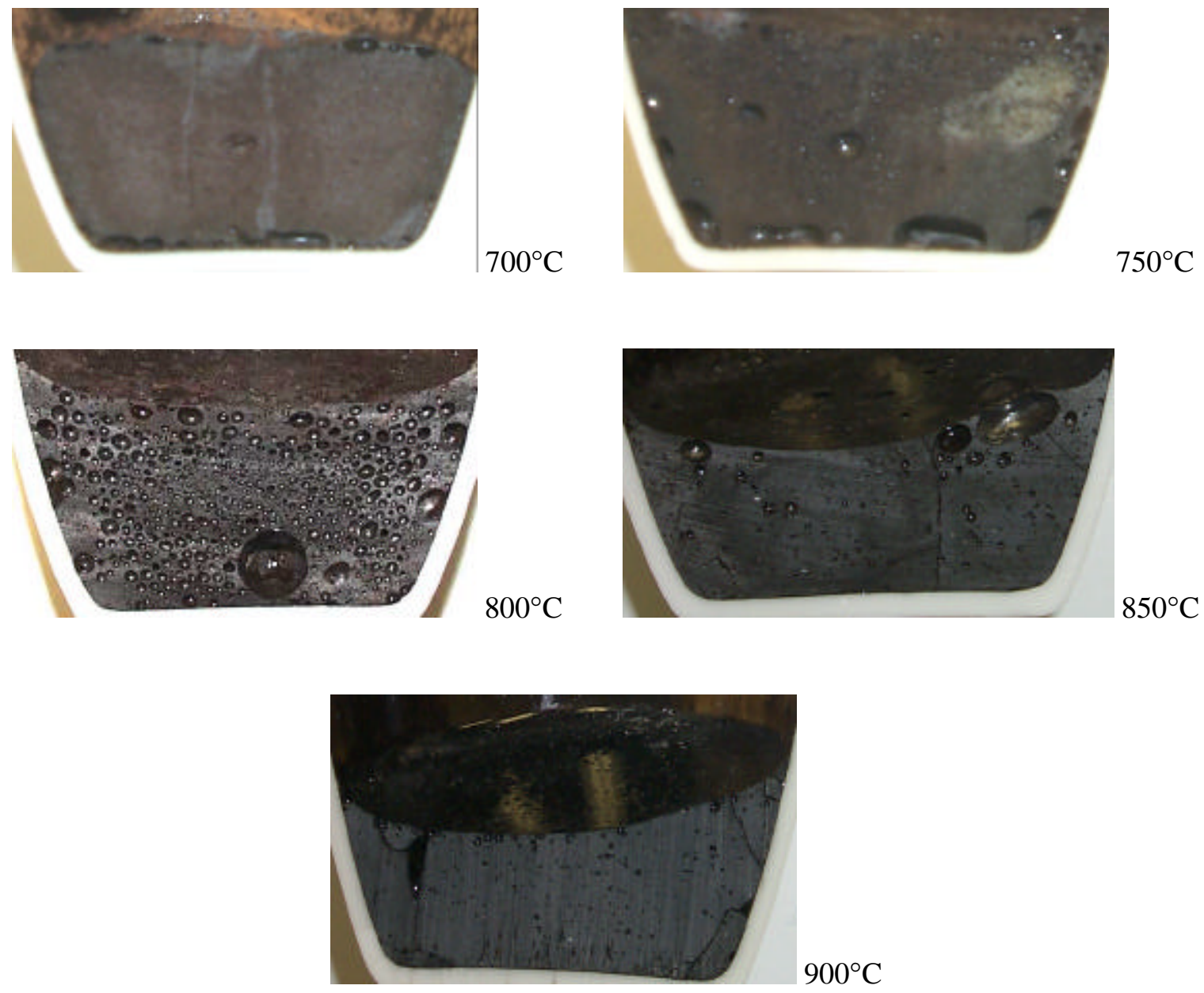

Figure 6. Frit 200 (Batch chemicals) with MB3.

In comparing Figure 5 with Figure 3 and Figure 6 with Figure 2, there are virtually no differences. For example, in comparing the pre-fabricated Frit 165 (Lot \#AX667974 canisters 3 \& 4) versus 165 from batch chemicals, the temperature with the worst foaming was $750^{\circ} \mathrm{C}$. It is apparent that the size and quantity of the bubbles for each option at this temperature are practically the same. Once at $800^{\circ} \mathrm{C}$, both frits are at the same stage again, where foam still remains, but the amount of bubbles is less. Strong similarities can be seen between Frit 200 (Lot \#CS) and 200 from batch chemicals as well, based on the isothermal crucible tests. Therefore, there appears to be no advantage of utilizing the batch chemical versions of Frits 165 and 200 over using the prefabricated frits. 


\subsection{Silica deficient frits $\mathbf{- 1 6 5}$ and $\mathbf{2 0 0}$}

Another option explored for Frits 165 and 200 was leaving out a certain percentage of the silica present in the original frit and adding it back at a later stage (for more details, see WSRC-TR-2001-00152). Compositionally the frits are the same, but instead of adding one component to the sludge (frit only), two components are added (a silica deficient frit plus $\left.\mathrm{SiO}_{2}\right)^{4}$. Frits 165 and 200 were tested at $25 \%, 50 \%$, and $75 \%$ silica deficiencies and the results are shown in Figures 7-12.

\subsubsection{Silica deficient Frit 165}

In analyzing these three separate, silica deficiencies of Frit 165, foaming problems occur for each - it is just a matter of when and how much. For the $25 \%$ and $50 \%$ silica deficiencies, the greatest amount of foam and volume expansion occurred at $750^{\circ} \mathrm{C}$. For the $75 \%$ deficiency it appears to begin to happen at $700^{\circ} \mathrm{C}$ and is probably worst somewhere between $700^{\circ} \mathrm{C}$ and $750^{\circ} \mathrm{C}$. The $75 \%$ silica deficiency foaming at a lower temperature than the $25 \%$ and $50 \%$ deficiencies can probably be attributed to the greater amount of $\mathrm{SiO}_{2}$ that was added separately from the silica deficient frit (see Lorier (2001) for more details). For all three, most of the foam is decreasing by $800^{\circ} \mathrm{C}$, and no bubbles appear any more once $900^{\circ} \mathrm{C}$ is reached.

\footnotetext{
${ }^{4}$ The required amount of "total" frit needed for one crucible test is 34.56 grams, and assume the frit is Frit 165 at $25 \%$ silica deficiency. Instead of adding 34.56 grams of pure Frit 165, 28.68 grams of $25 \%$ silica deficient Frit 165 plus 5.88 grams of $\mathrm{SiO}_{2}$ are added.
} 
Immobilization Technology Section

Savannah River Technology Center

Rev. 0

Westinghouse Savannah River Company

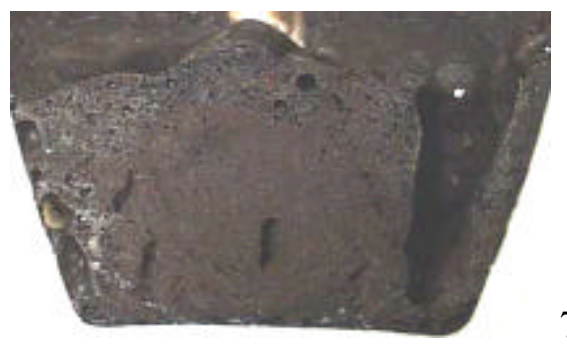

$700^{\circ} \mathrm{C}$
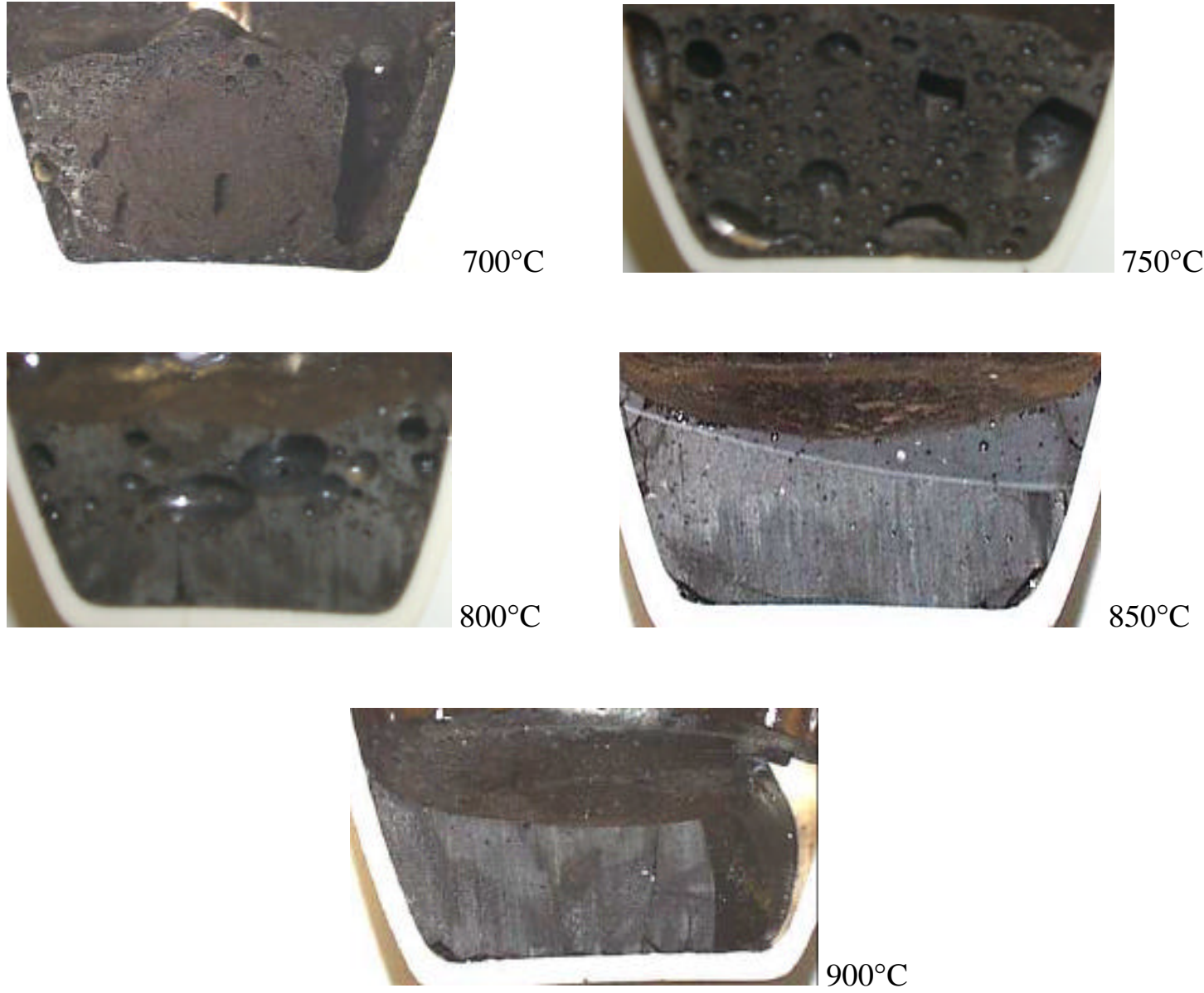

Figure 7. Frit 165 (25\% silica deficiency) with MB3. 
Immobilization Technology Section

Savannah River Technology Center

Westinghouse Savannah River Company
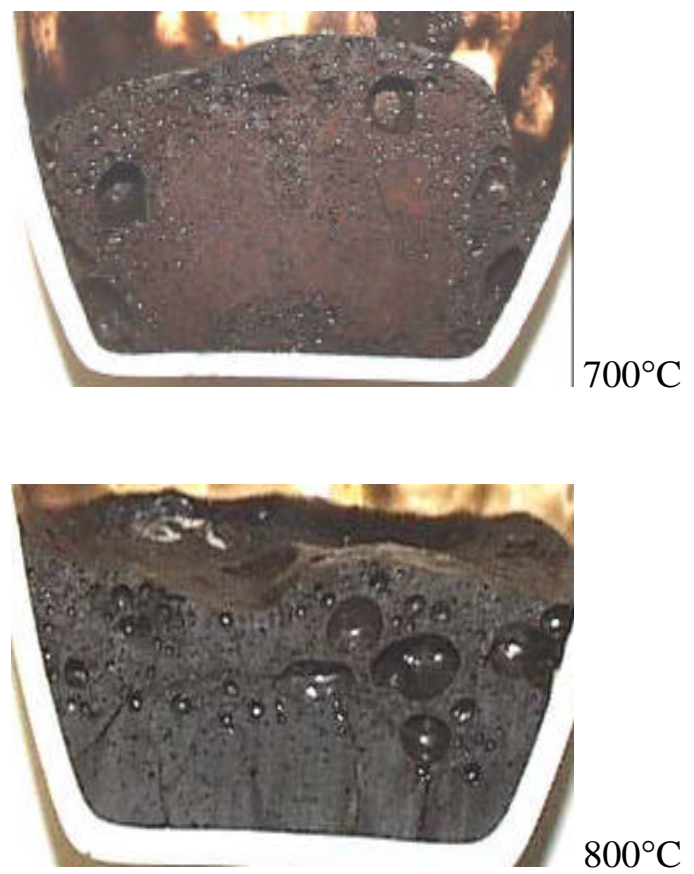

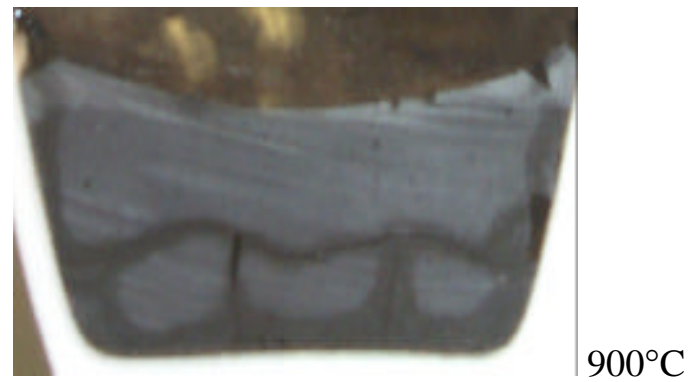

WSRC-TR-2001-00151

Rev. 0
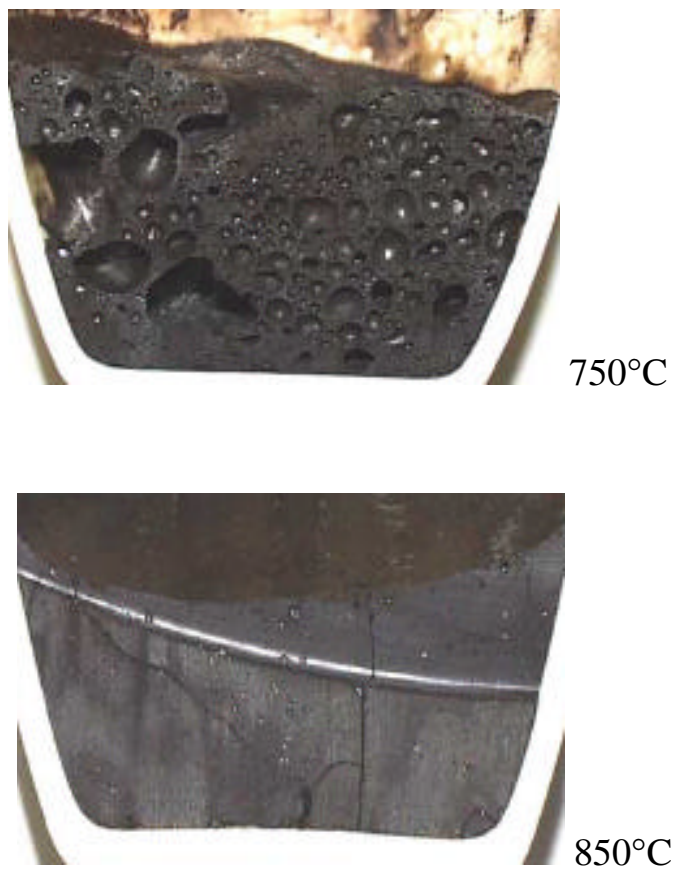

Figure 8. Frit 165 (50\% silica deficiency) with MB3. 

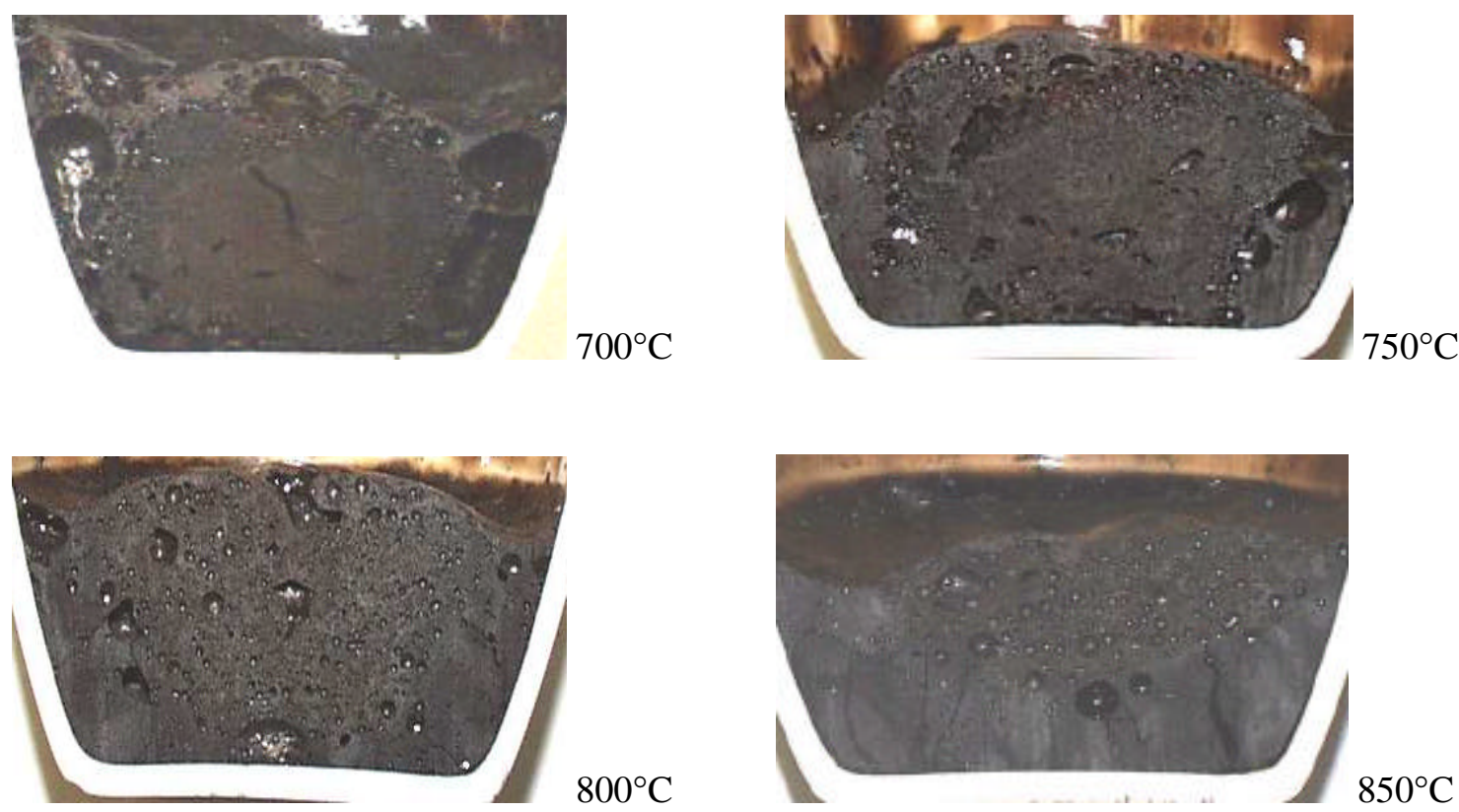

$800^{\circ} \mathrm{C}$
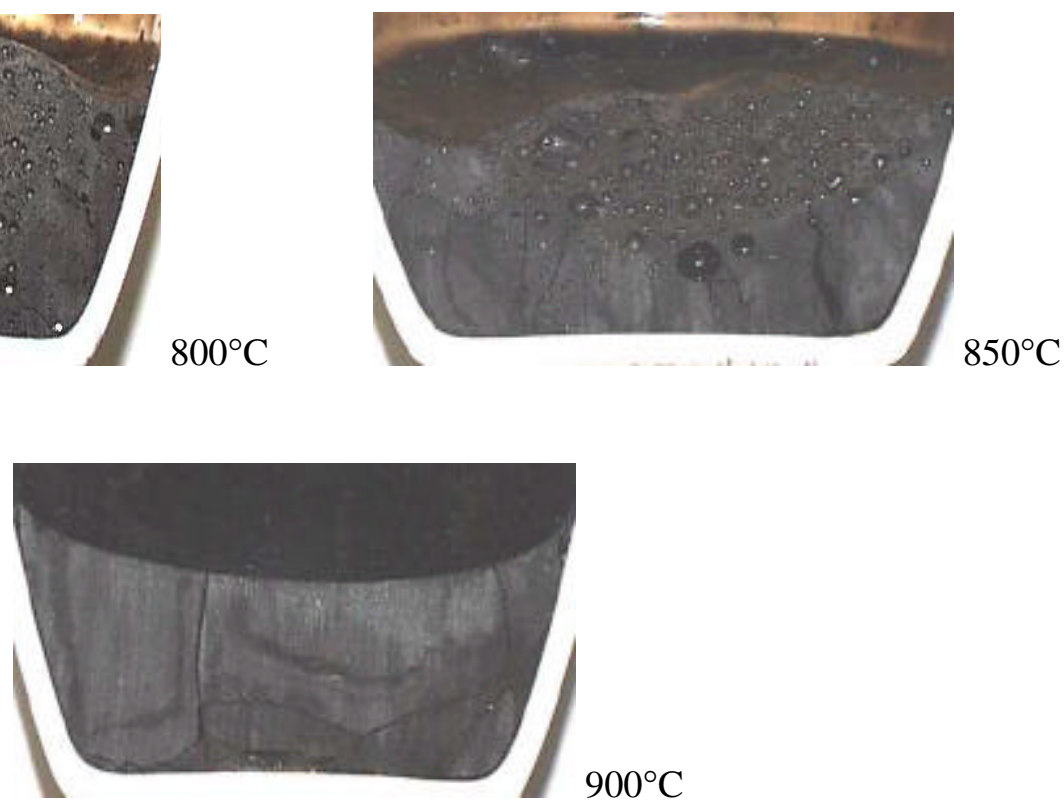

Figure 9. Frit 165 (75\% silica deficiency) with MB3.

\subsubsection{Silica deficient Frit 200}

Trends similar to those of silica deficient Frit 165 were observed for the silica deficient 200 frits For the $25 \%$ and $50 \%$ deficiencies of Frit 200, severe foam (batch expansion) appeared at $700^{\circ} \mathrm{C}$ with the most severe foaming and batch expansion at $750^{\circ} \mathrm{C}$. However, the foam seemed to endure to higher temperatures than those of 165 . Once at $900^{\circ} \mathrm{C}$ though, virtually all bubbles were gone. For the $75 \%$ silica deficient 200 frit, not much foam appeared until $900^{\circ} \mathrm{C}$ though, but most of the bubbles resided at the top of the glass melt. 

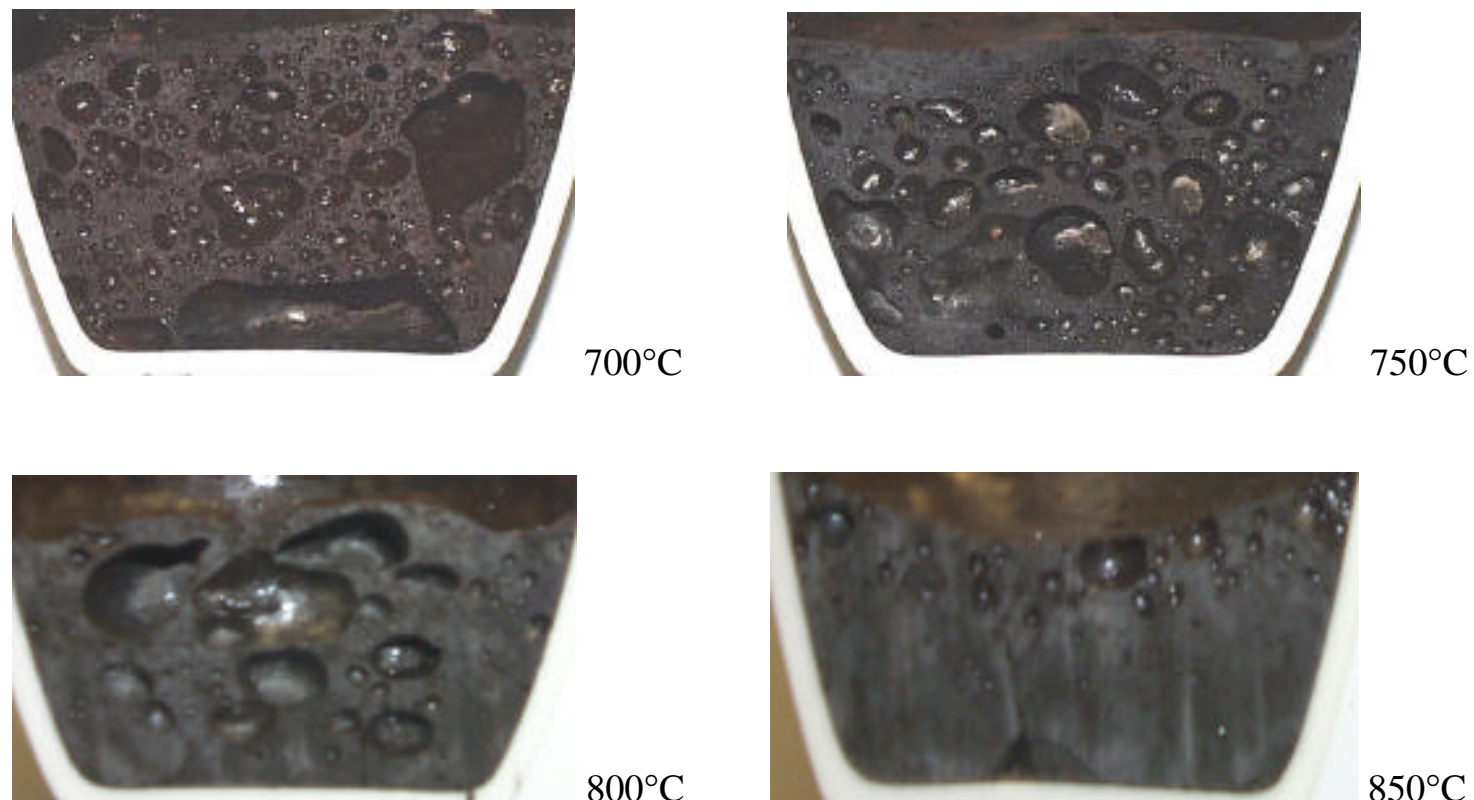

$800^{\circ} \mathrm{C}$
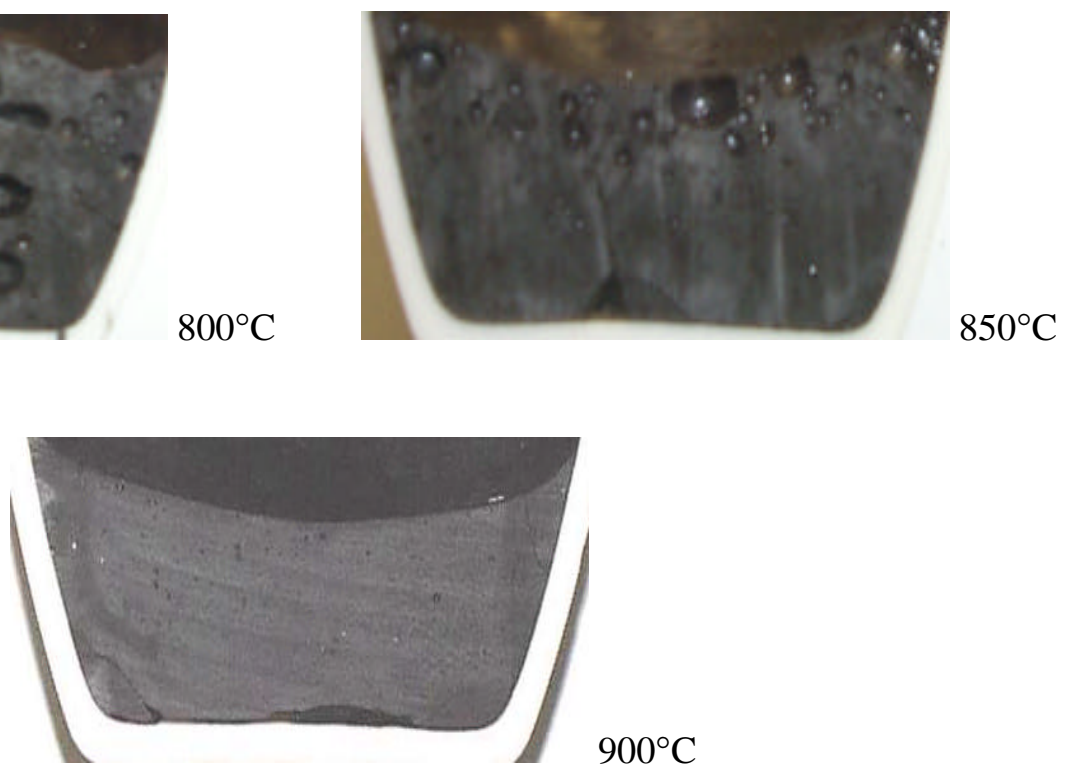

Figure 10. Frit 200 (25\% silica deficiency) with MB3. 
Immobilization Technology Section

Savannah River Technology Center

Rev. 0

Westinghouse Savannah River Company
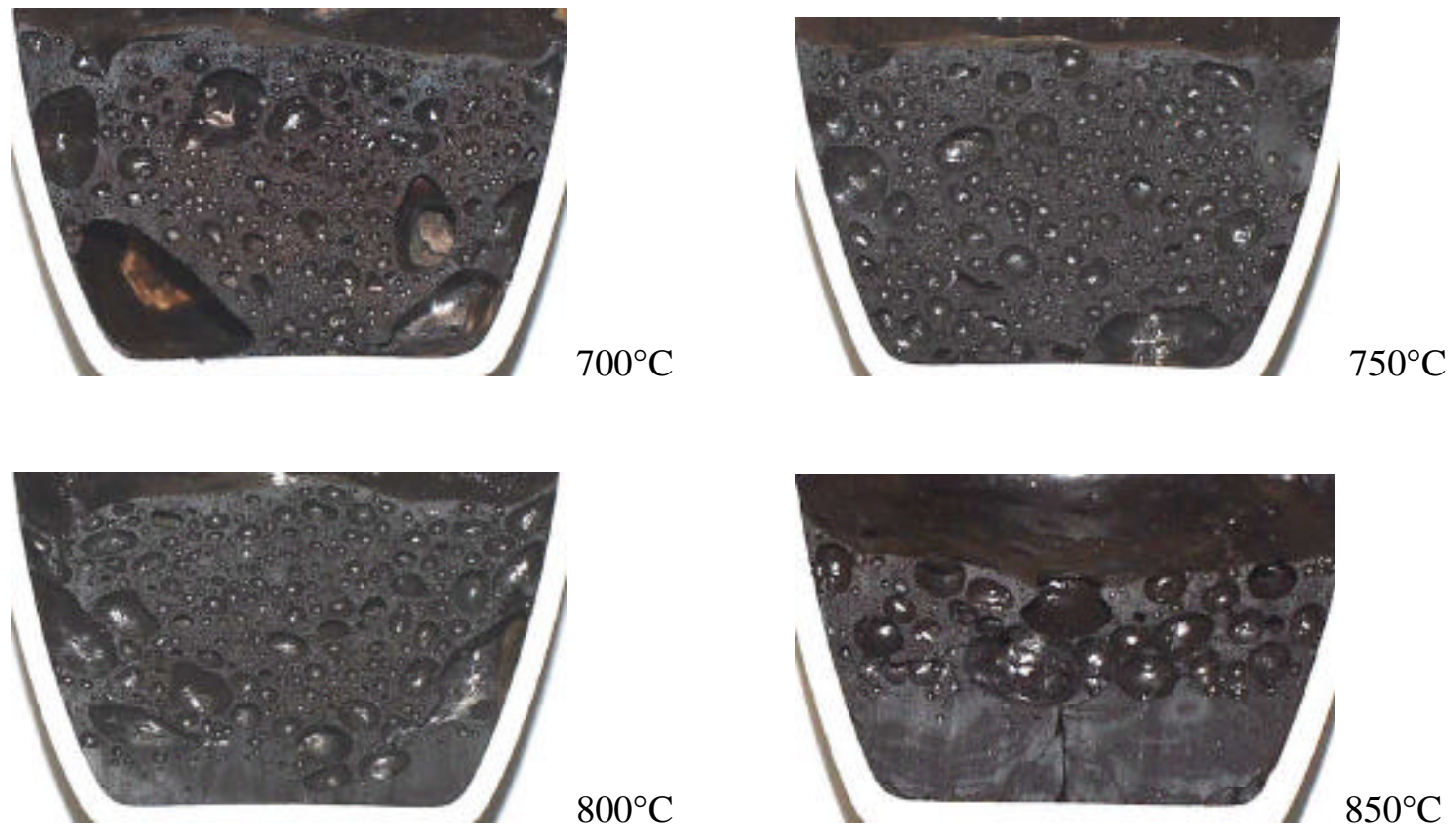

$800^{\circ} \mathrm{C}$
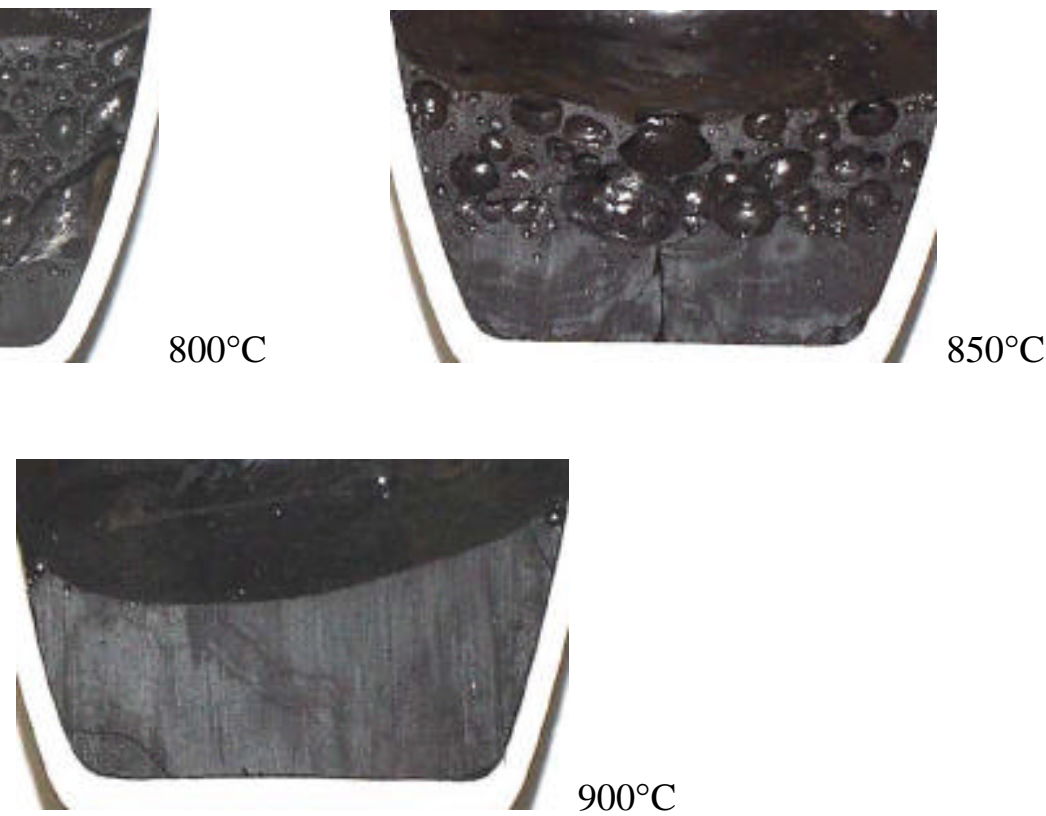

Figure 11. Frit 200 (50\% silica deficiency) with MB3. 

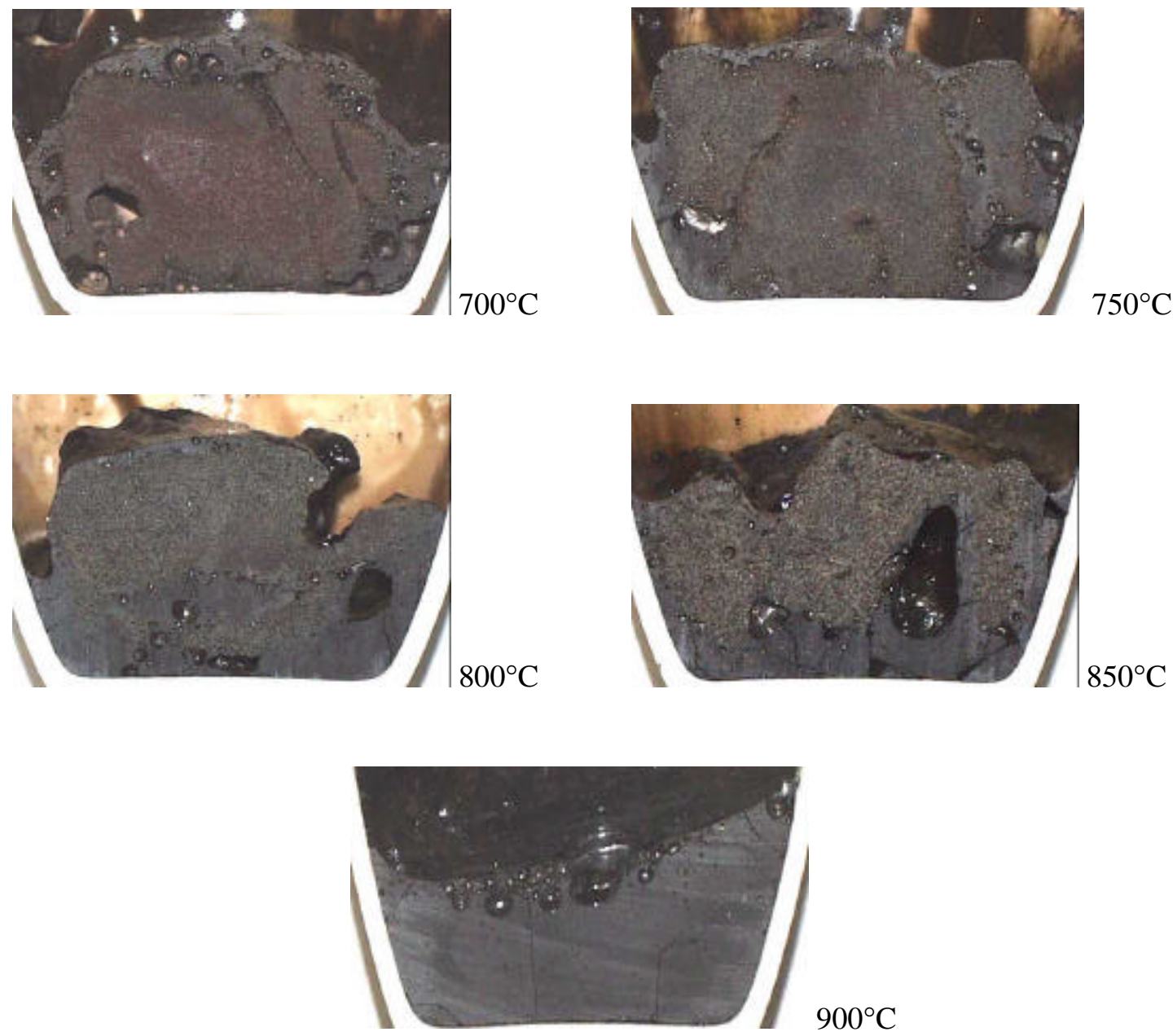

Figure 12. Frit 200 (75\% silica deficiency) with MB3.

Analysis of these silica deficiency tests shows several advantages of not utilizing silica deficient frits versus Frit 165 or 200 . The amounts and duration of the foam in the cases of silica deficient 165 and 200 are greater than the pure frits. Another issue is that the combination of a silica deficient frit plus $\mathrm{SiO}_{2}$ might melt too slowly because the rate-limiting step may be the dissolution of the $\mathrm{SiO}_{2}$ into the glass. This is especially evidenced by the $75 \%$ silica deficient frits. Other problems include density differences, sampling issues in the SME if implemented in DWPF, and qualification concerns. Finally, having a "two-component" frit by adding a silica deficient frit and $\mathrm{SiO}_{2}$ separately complicates the process over only adding a pure frit (single component). 


\subsection{Frit 202}

Frit 202 contains the same components as Frit 200, but is more refractory due to the increased amount of $\mathrm{SiO}_{2}$ and lesser alkali and boron contents. Testing was conducted with this frit to determine whether or not creating a more viscous melt affects the melt rate of MB3. The results are shown in Figure 13.
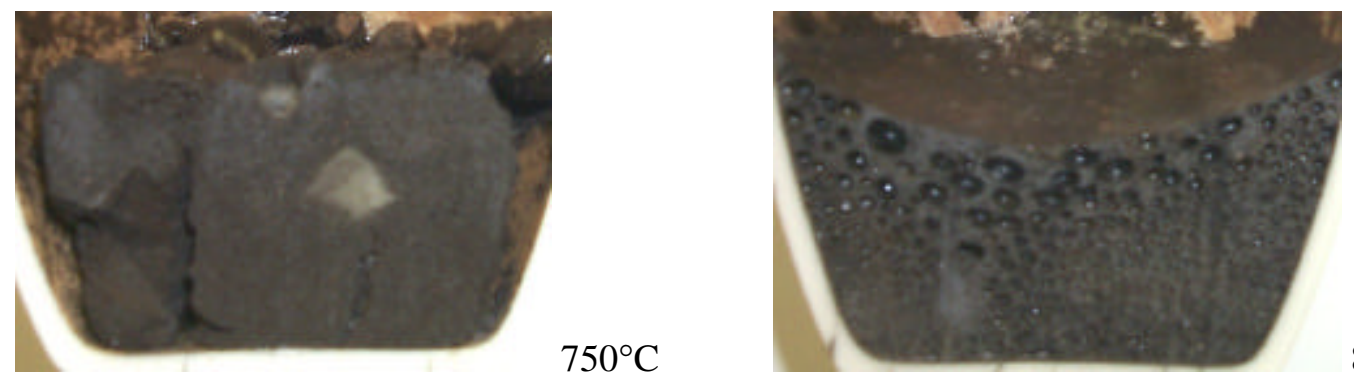

$800^{\circ} \mathrm{C}$

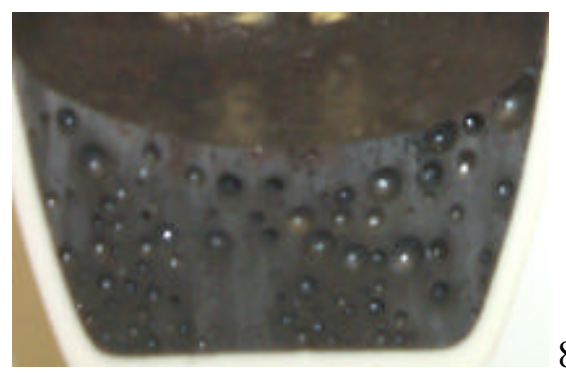

$850^{\circ} \mathrm{C}$

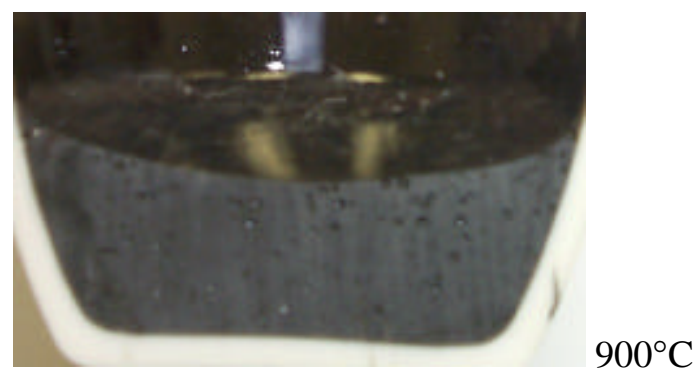

Figure 13. Frit 202 with MB3.

Being more refractory causes Frit 202 to not melt as quickly as other frits that have a lesser silica content. That is why no figure appears for Frit 202 at $700^{\circ} \mathrm{C}-$ sintering of the raw material had not occurred to the point that the sample could be cross-sectioned. At $750^{\circ} \mathrm{C}$, the sample is just forming a sintered mass. At $800^{\circ} \mathrm{C}$, the temperature of worst foam in this case, there was some slight volume expansion up the sides of the crucible and many small to medium bubbles materialized throughout the melt. Several larger bubbles remained at $850^{\circ} \mathrm{C}$, but there were fewer of them relative to those at $800^{\circ} \mathrm{C}$, and by $900^{\circ} \mathrm{C}$ all foam/batch expansion had subsided and only tiny residual bubbles remained in the complete glass melt. 


\subsection{Alternative frits}

Twelve alternative frits, developed through a joint SRTC/PNNL effort, were recommended by the melt rate team for further testing in order to evaluate melt rate of MB3. The criteria for how these twelve frits were chosen are: 1) boron in glass ranges $5 \%<\mathrm{B} \leq 11 \%, 2$ ) no non-lithium frits (minimum 3.5 mass\%), 3) total alkali $\leq 20 \%$, 4) no $\mathrm{ZrO}_{2}, 5$ ) no $\mathrm{Al}_{2} \mathrm{O}_{3}$, and 6) need to push $\mathrm{Li}_{2} \mathrm{O}$ limits (Peeler et al. 2001; WSRC-NB-2000-00144). The frits and their compositions (mass percent) are listed in Table II in subsection 3.2, and a summary of the major observations in the crucible tests for each frit is given in Tables III and IV of the Appendix.

\subsubsection{Frit 303}

At $700^{\circ} \mathrm{C}$, the sample was not sintered sufficiently to enable cross-sectioning of the crucible, so no figure appears. At $750^{\circ} \mathrm{C}$, small bubbles began to form throughout the melt, but a majority of the batch was still "unreacted." The greatest batch expansion and foam occurred at $800^{\circ} \mathrm{C}$, where many large bubbles had formed. Significant volume reduction occurred by $850^{\circ} \mathrm{C}$, with residual bubbles remaining at the top of the melt, and at $900^{\circ} \mathrm{C}$ a complete glass had formed.
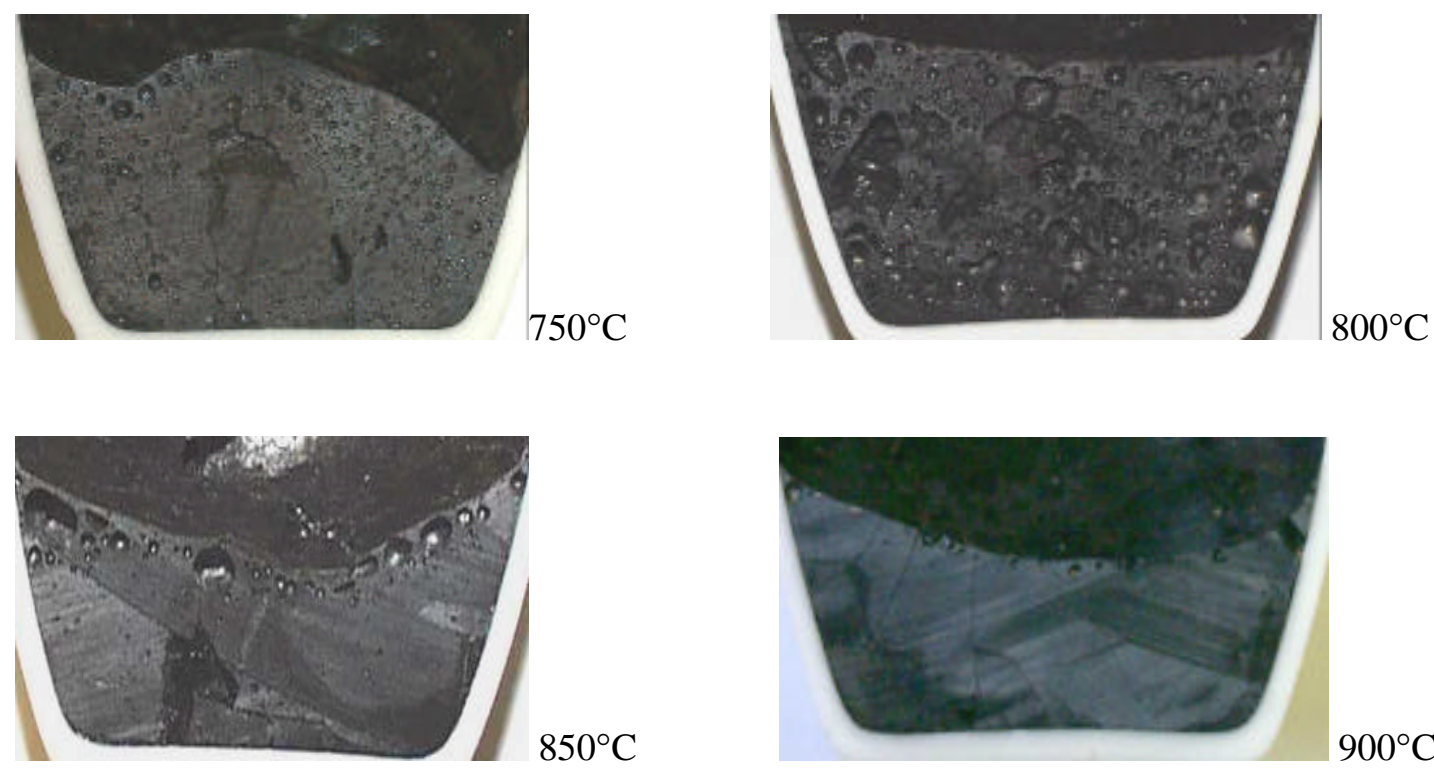

$850^{\circ} \mathrm{C}$

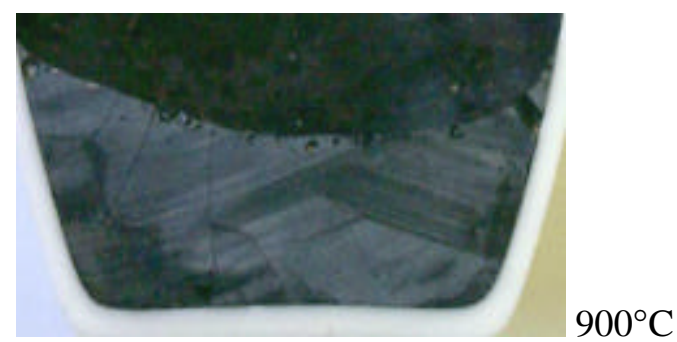

Figure 14. Frit 303 with MB3. 


\subsubsection{Frit 304}

The greatest foaming problems/batch expansion for Frit 304 occurred at a lower temperature than those of any other frits tested. Large bubbles throughout and batch expansion were evident at $700^{\circ} \mathrm{C}$, but the batch volume was reduced greatly by $750^{\circ} \mathrm{C}^{5}$. At $800^{\circ} \mathrm{C}$, only small residual bubbles remained; and at temperatures of $850^{\circ} \mathrm{C}$ and above a complete glass sample had formed. By this isothermal analysis it appears that Frit 304 melts quite rapidly.
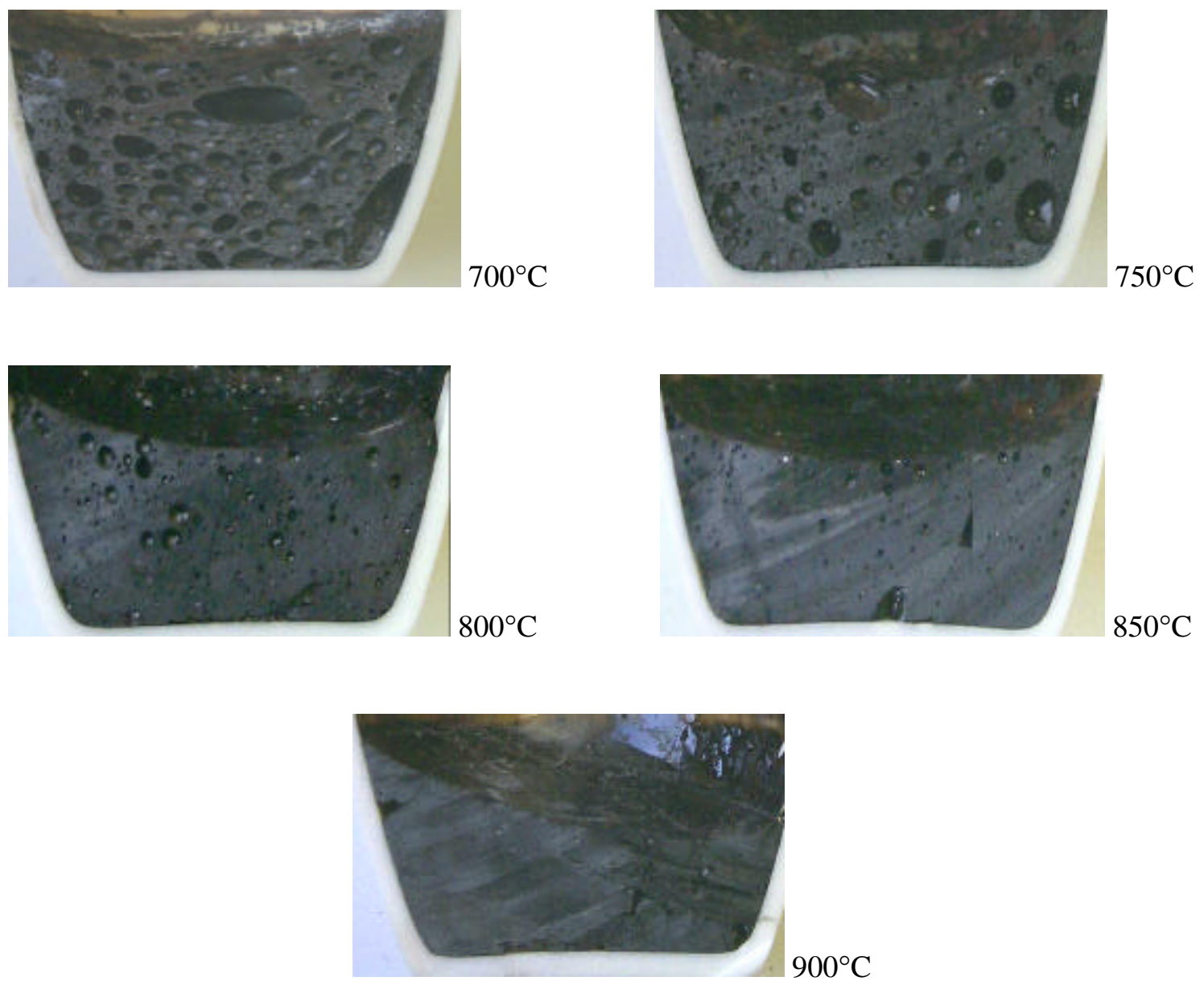

Figure 15. Frit 304 with MB3.

\footnotetext{
${ }^{5}$ The figures of all crucibles are not on the same exact scale, so small differences may be difficult to see.
} 


\subsubsection{Frit 307}

For Frit 307 , the sample was a sintered mass at $750^{\circ} \mathrm{C}$ and below, with no expansion or glass

phase observed. By $800^{\circ} \mathrm{C}$ though, the batch had expanded with many medium and large bubbles present throughout the melt. At $850^{\circ} \mathrm{C}$, only small bubbles were trapped at the melt surface. The sample was glass at $900^{\circ} \mathrm{C}$, with no bubbles remaining (the dark, triangular portion of the picture is where a small piece of glass broke off during sectioning).
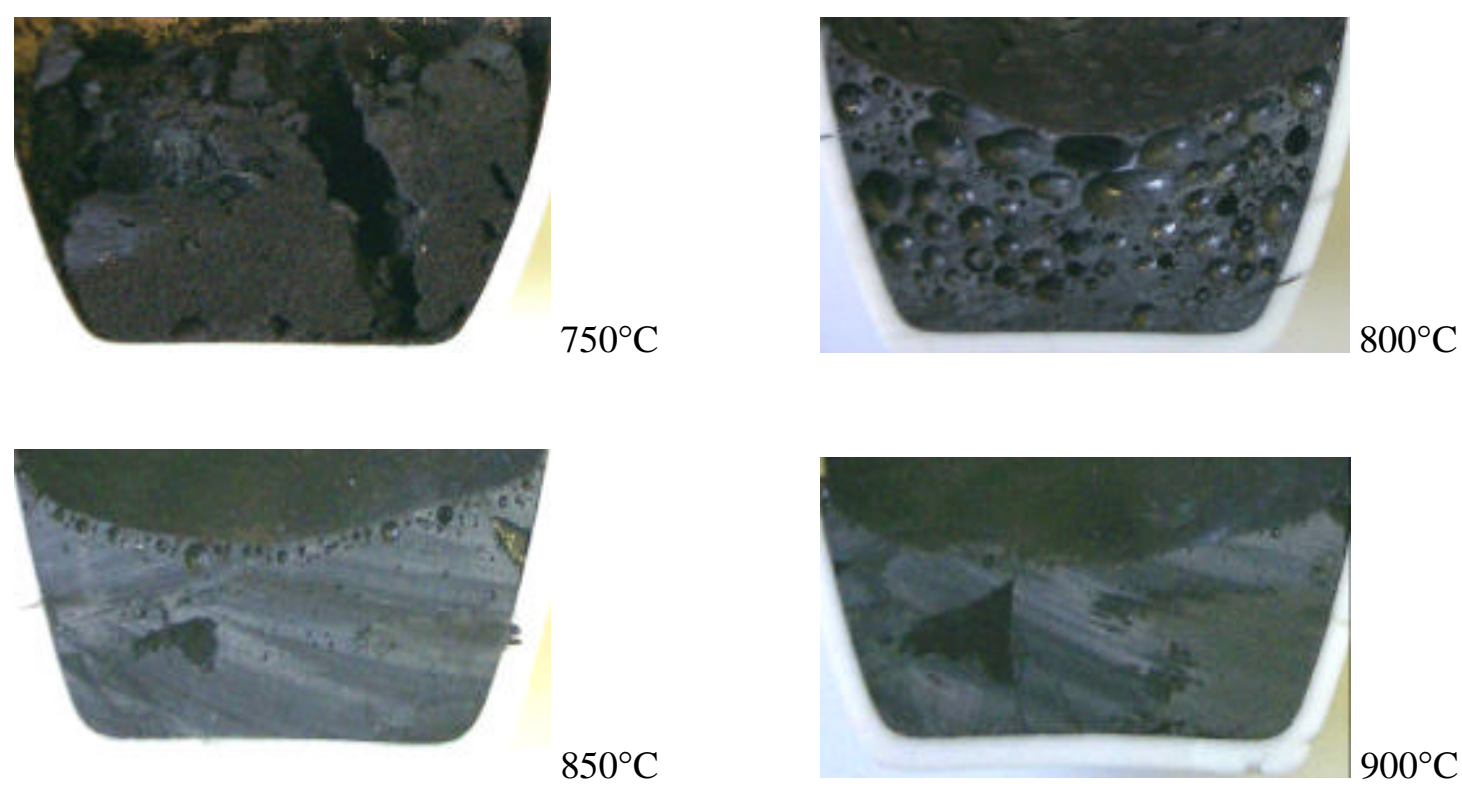

Figure 16. Frit 307 with MB3. 


\subsubsection{Frit 313}

The batch with Frit 313 was basically a sintered mass at both $750^{\circ} \mathrm{C}$ and $800^{\circ} \mathrm{C}$, with only slightly more reaction and volume reduction at $800^{\circ} \mathrm{C}$. Volume reduction continued at $850^{\circ} \mathrm{C}$, with only small bubbles residing at the top of the melt. By $900^{\circ} \mathrm{C}$, all bubbles had disappeared and a complete glass had formed. By observation, it does not seem that Frit 313 has a significant foam or batch expansion potential with MB3, based on these crucible tests.

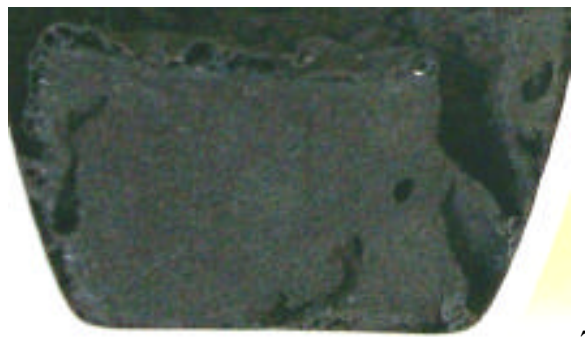

$750^{\circ} \mathrm{C}$
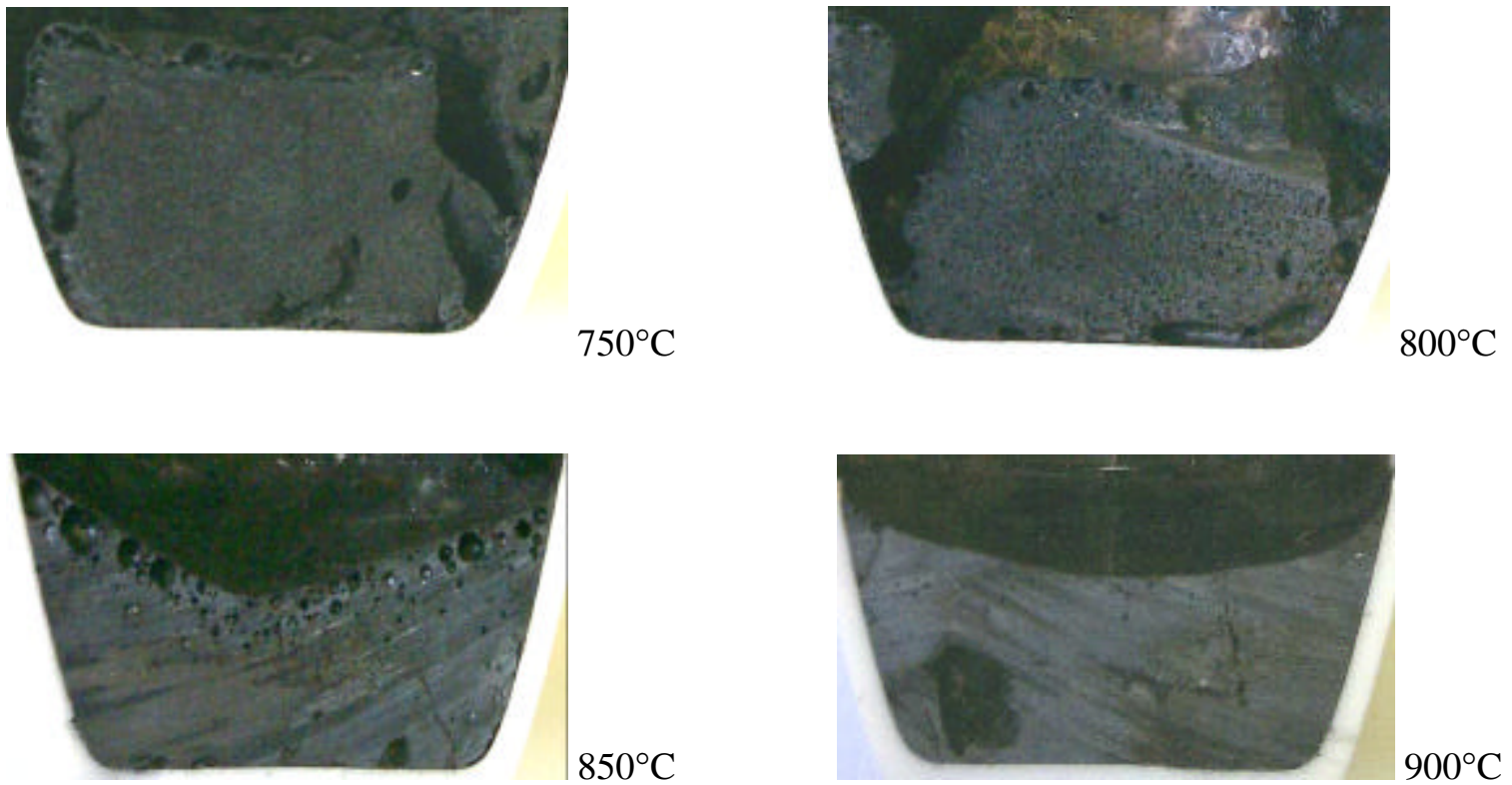

Figure 17. Frit 313 with MB3. 


\subsubsection{Frit 314}

At $700^{\circ} \mathrm{C}$, the Frit 314 sample was still a sintered mass with a mostly unreacted batch. More melting occurred at $750^{\circ} \mathrm{C}$, where small and medium-sized bubbles formed. The foam was worst at $800^{\circ} \mathrm{C}$, where larger bubbles were present throughout the entire melt. At $850^{\circ} \mathrm{C}$, the bubbles that persisted were in the top half of the melt with a complete glass beneath. No bubbles remained once at $900^{\circ} \mathrm{C}$.
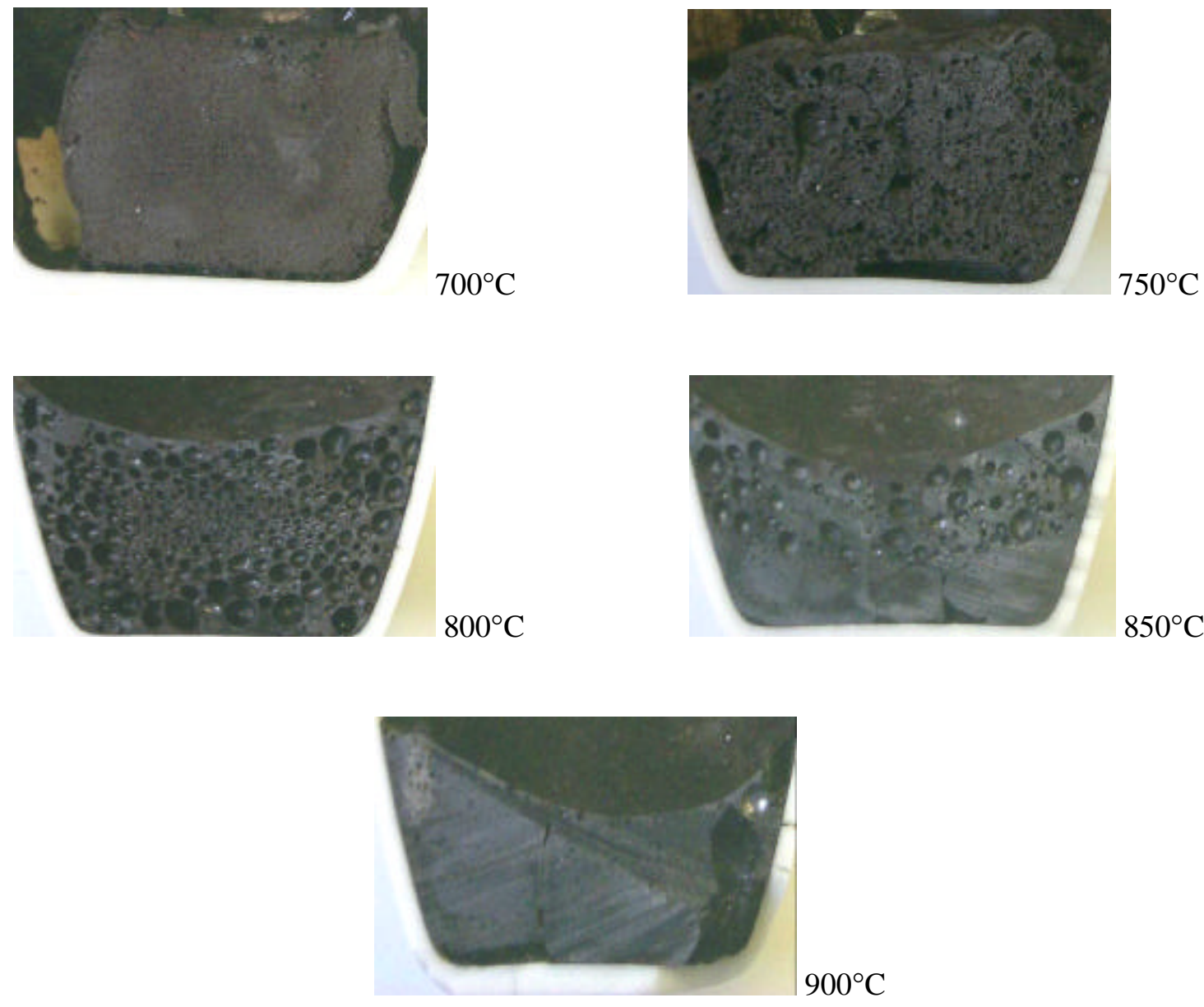

Figure 18. Frit 314 with MB3. 


\subsubsection{Frit 315}

Of the frits tested, Frit 315 is the only one that contained only three components $-\mathrm{B}_{2} \mathrm{O}_{3}, \mathrm{Li}_{2} \mathrm{O}$, and $\mathrm{SiO}_{2}$. All the others contained at least four components. For Frit 315 at $750^{\circ} \mathrm{C}$, most of the sample was a sintered mass, with an initial liquid formed at the surface. At $800^{\circ} \mathrm{C}$, volume reduction occurred with a few medium bubbles formed towards the center of the melt. Basically the same happened at $850^{\circ} \mathrm{C}$, and by $900^{\circ} \mathrm{C}$, only tiny bubbles remained in the top half of the melt. So based on these crucible-scale tests, Frit 315 does not seem to have a significant foam or batch expansion problem.
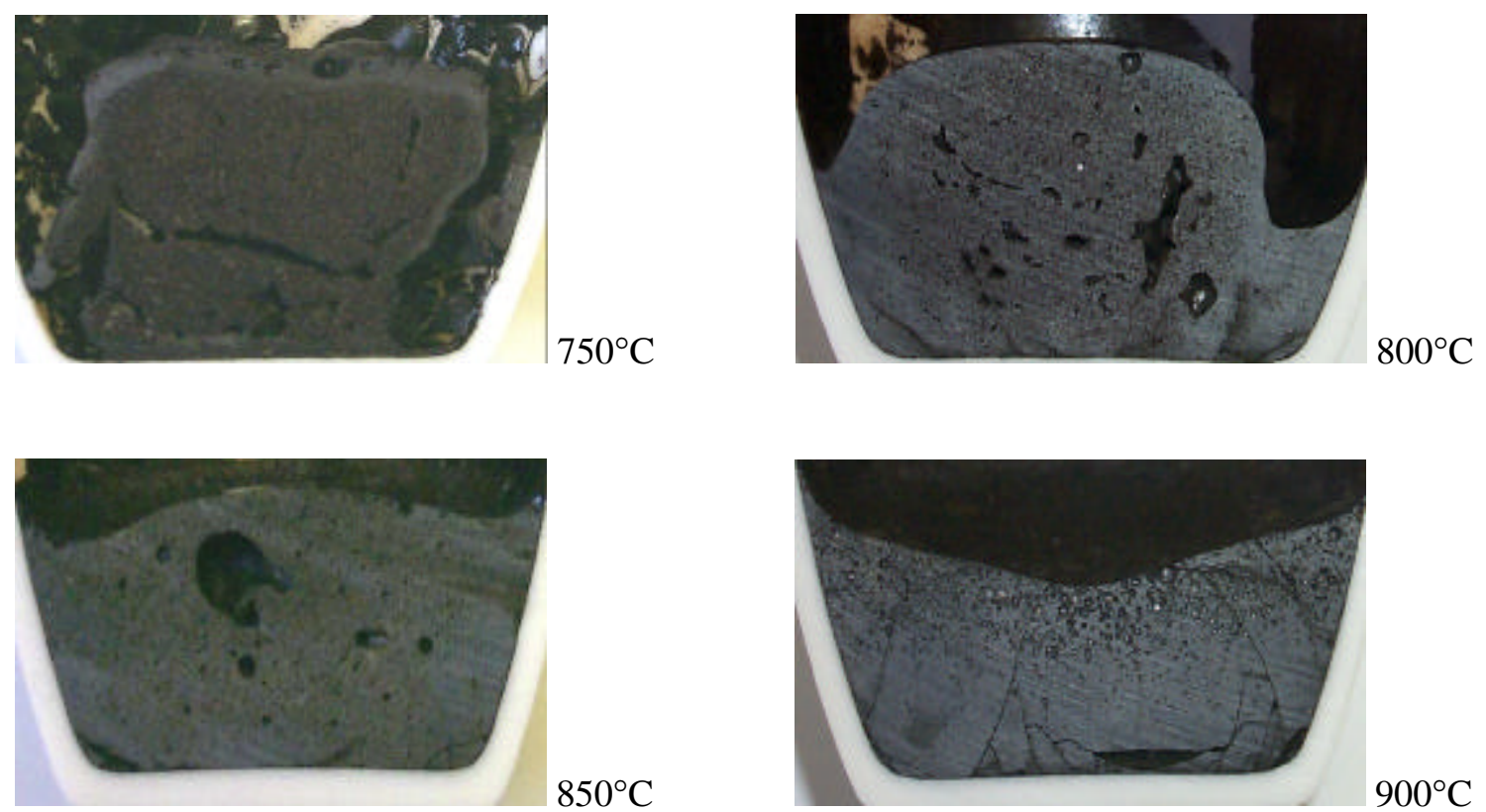

Figure 19. Frit 315 with MB3. 


\subsubsection{Frit 320}

The samples of Frit 320 at $700^{\circ} \mathrm{C}$ and $750^{\circ} \mathrm{C}$ were essentially "unreacted", with some initial melting occurring at $750^{\circ} \mathrm{C}$. At $750^{\circ} \mathrm{C}$, larger bubbles began to form at the surface and along the sides. The temperature of greatest foam was $800^{\circ} \mathrm{C}$, where numerous small, medium, and large bubbles formed throughout the melt. Virtually all foam was gone once $850^{\circ} \mathrm{C}$ was reached, with only few residual bubbles remaining. By $900^{\circ} \mathrm{C}$, the melt was in a complete glass form.
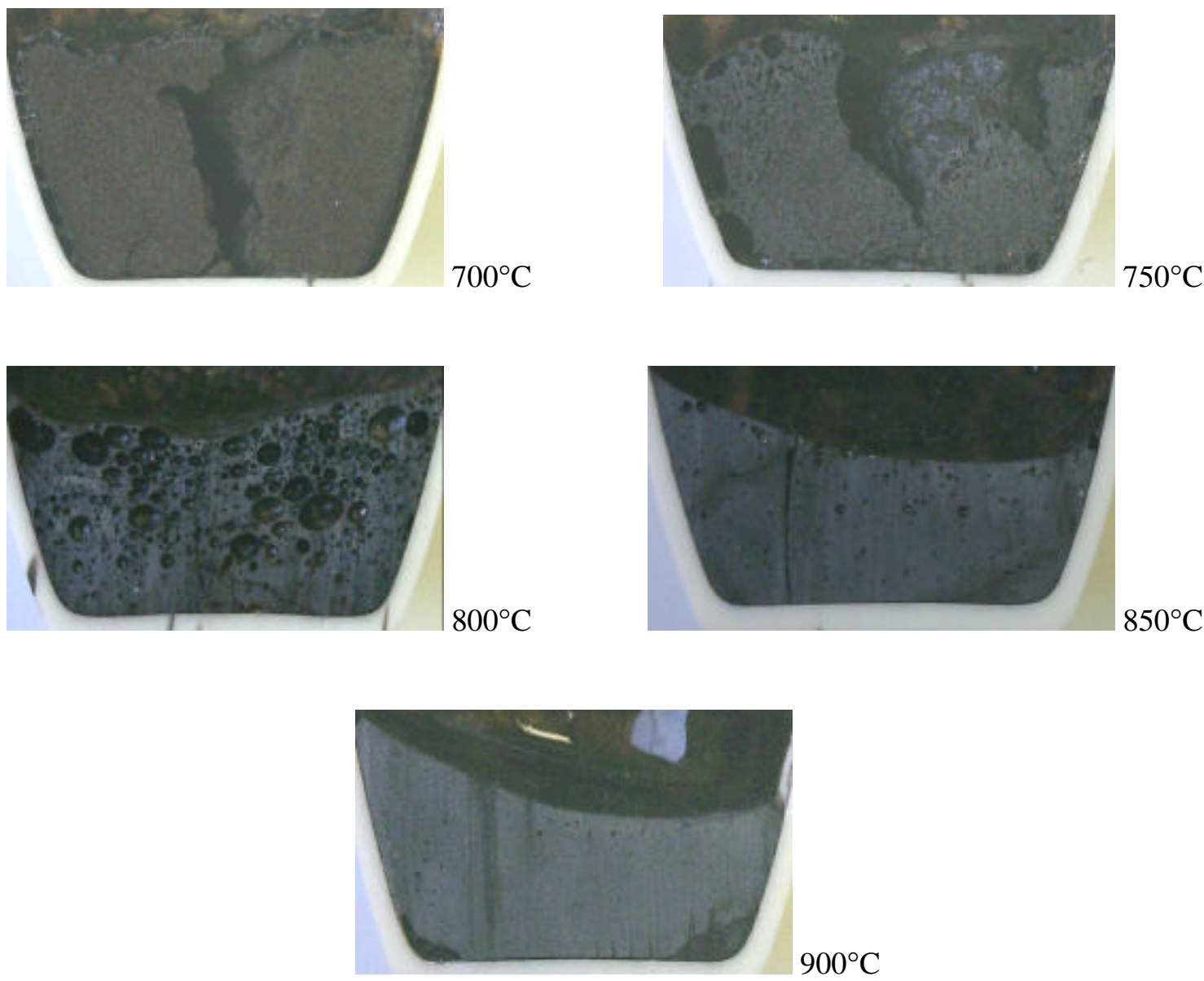

Figure 20. Frit 320 with MB3. 


\subsubsection{Frit 322}

The worst foam formation and expansion for Frit 322 was observed at $750^{\circ} \mathrm{C}$, but only small bubbles were noted throughout the melt. Medium or large bubbles never materialized. At $800^{\circ} \mathrm{C}$, the bubbles were even smaller and a slight volume reduction had occurred. Only residual bubbles were present near the tops of the melts at $850^{\circ} \mathrm{C}$ and $900^{\circ} \mathrm{C}$. The samples were complete glasses at these temperatures.
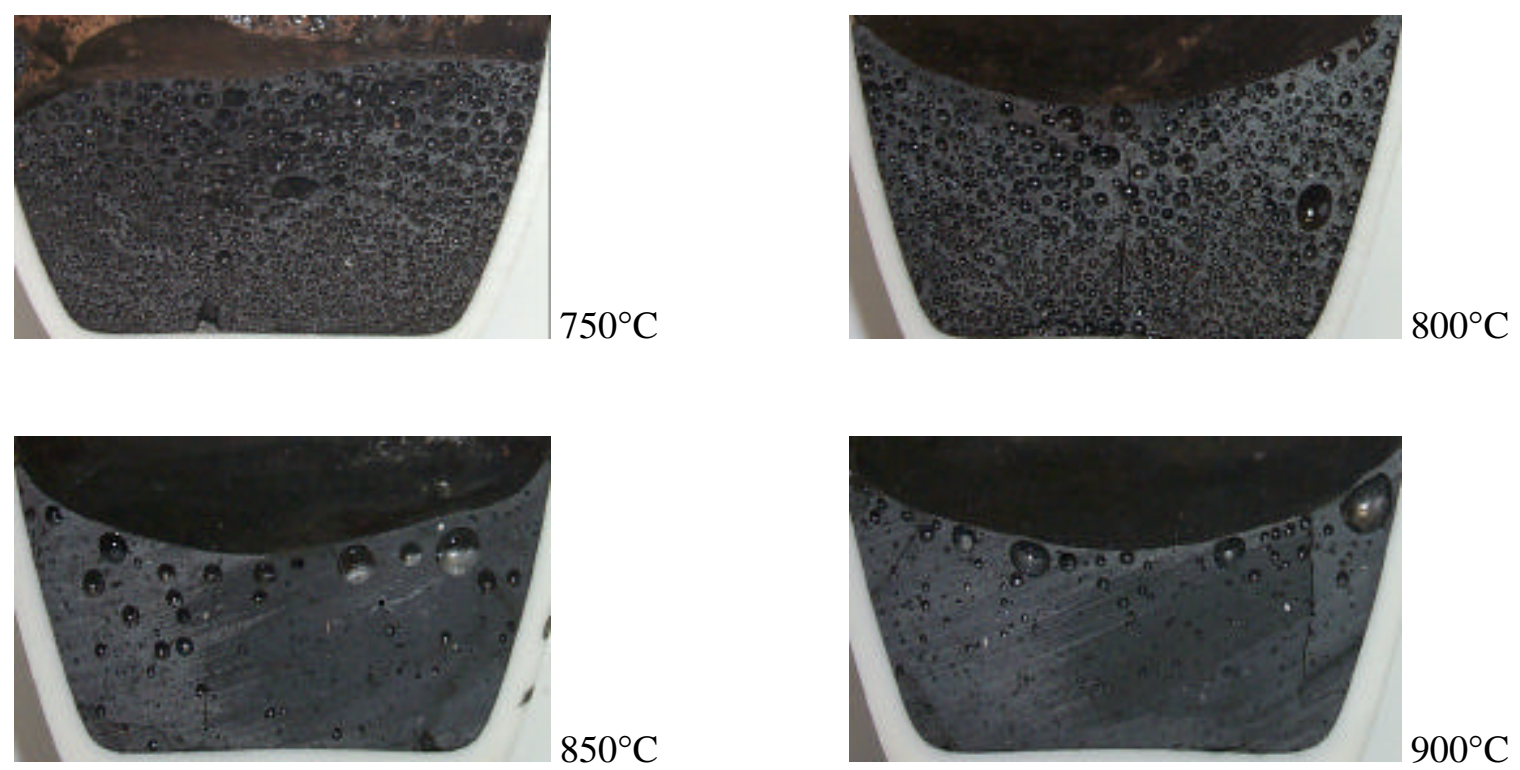

Figure 21. Frit 322 with MB3. 


\subsubsection{Frit 323}

A sintered mass formed for Frit 323 at $700^{\circ} \mathrm{C}$. By $750^{\circ} \mathrm{C}$, many tiny bubbles formed throughout the melt, along with a few medium-sized bubbles. A slight volume reduction occurred at $800^{\circ} \mathrm{C}$ as a glass began to form, but small bubbles resided in the entire melt. At $850^{\circ} \mathrm{C}$ only a few residual bubbles remained in the glass. The same is true for the sample at $900^{\circ} \mathrm{C}$, where virtually no bubbles remained.
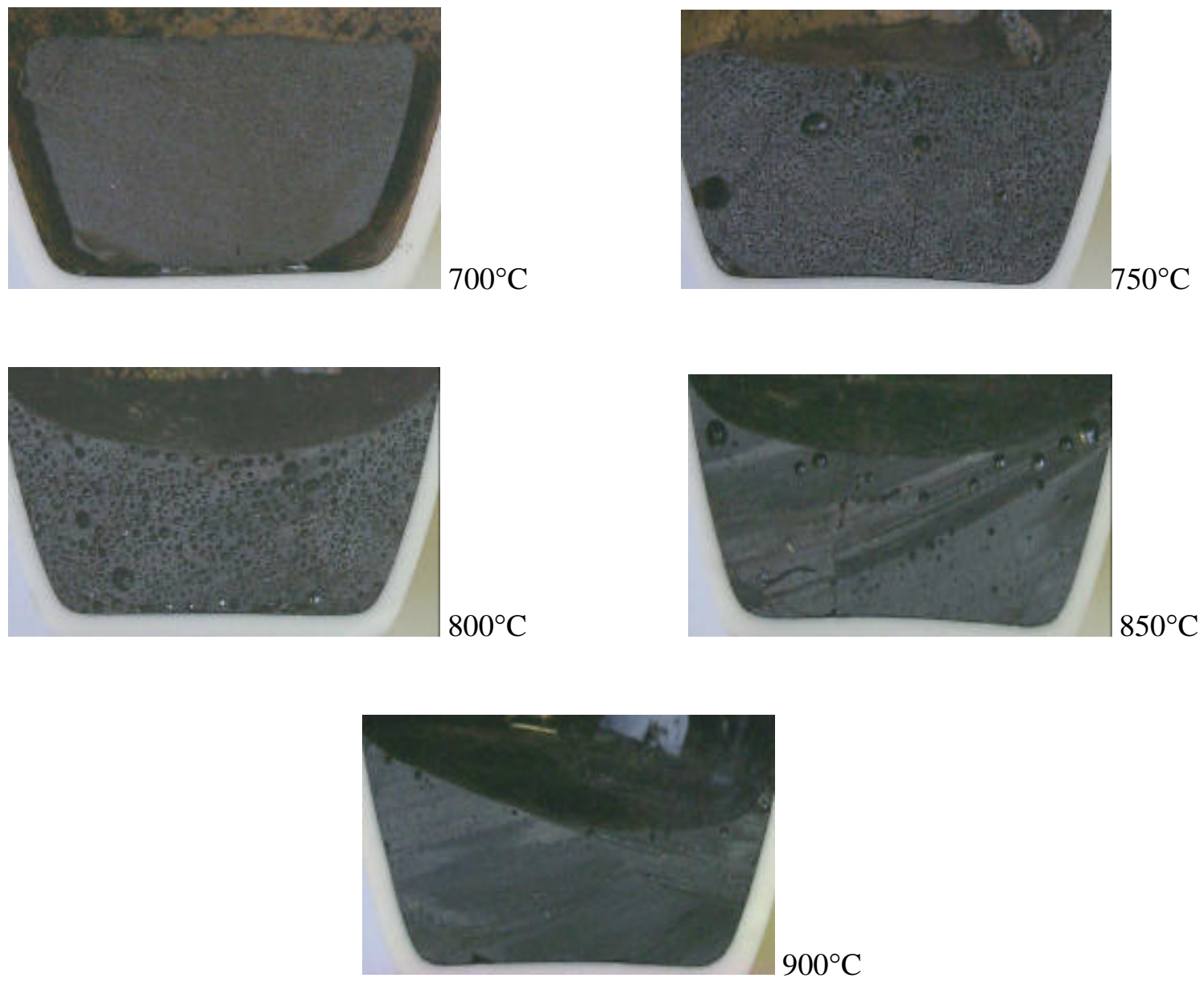

Figure 22. Frit 323 with MB3. 


\subsubsection{Frit 324}

Frit 324 differed from Frit 323 compositionally by reversing the concentrations of sodium and lithium. Frit 323 had the higher sodium content, while Frit 324 had the higher lithium content. At $750^{\circ} \mathrm{C}$, the Frit 324 sample was still a sintered mass where little melting had occurred. At $800^{\circ} \mathrm{C}$, tiny bubbles began to form, with one very large bubble in the middle of the melt. The foam resided mostly at the top of the melt at $850^{\circ} \mathrm{C}$. All bubbles had subsided by $900^{\circ} \mathrm{C}$. Comparison of Frits 323 and 324 indicates that Frit 324 would be a more preferred frit because the foam potential did not seem as dramatic as Frit 323, based on these isothermal crucible tests.
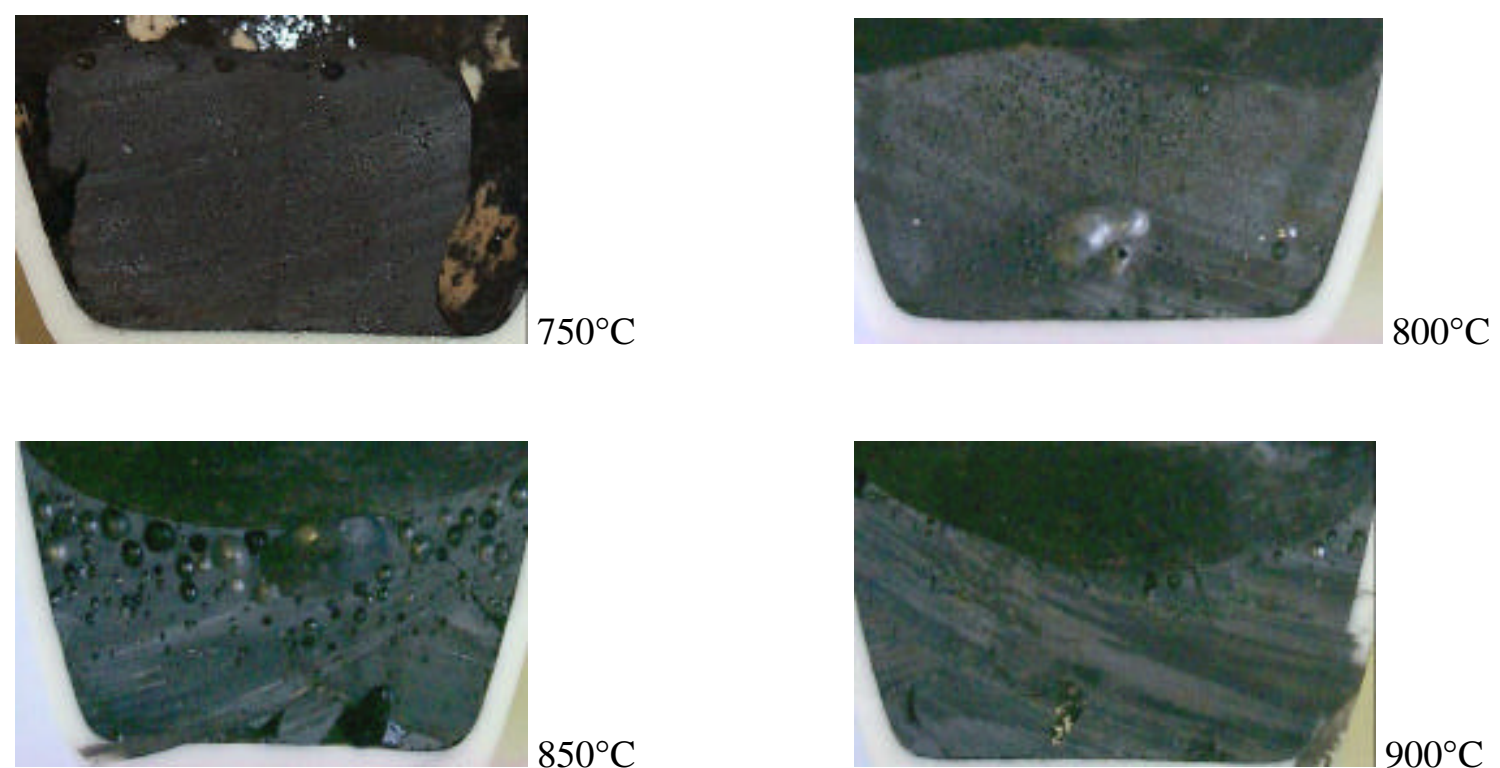

Figure 23. Frit 324 with MB3. 


\subsubsection{Frit 325}

When tested with Macrobatch 3, Frit 325 was combined with Frit 202 in a 1:1 ratio and then mixed with the sludge. At $700^{\circ} \mathrm{C}$, the sample was sintered, but by $750^{\circ} \mathrm{C}$, melting had begun and foam had formed throughout the entire melt. One very large bubble formed in the middle of the melt at $800^{\circ} \mathrm{C}$, along with tiny to medium-sized bubbles throughout. Residual bubbles persisted at $850^{\circ} \mathrm{C}$, and the melt was completely glass by $900^{\circ} \mathrm{C}$ (a piece of glass broke away from the rest of the sample upon sectioning).
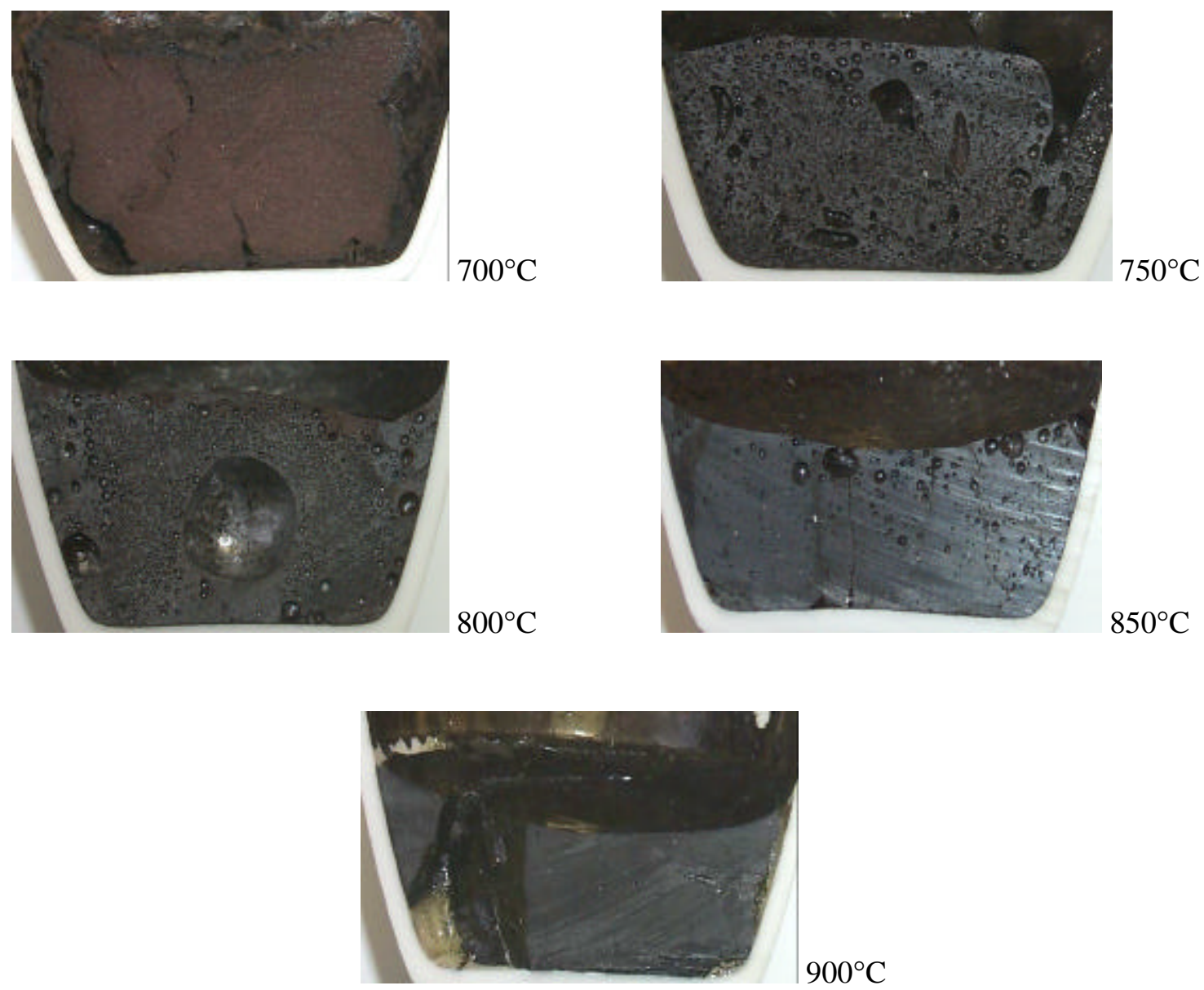

Figure 24. Frit 325 with MB3. 


\subsubsection{Frit 326}

Frit 326 is compositionally the same as Frit 320, except that 1 mass $\% \mathrm{MgO}$ has been added at the expense of 1 mass $\% \mathrm{Na}_{2} \mathrm{O}$ (see Table 2). Since adding $\mathrm{MgO}$ to a frit may augment the final glass' performance/durability, it was decided to add it and evaluate how or if it affected melt rate or melt rate behavior as defined by the tests utilized in this study. Adding MgO to Frit 320 was based on the following criteria: 1) the viscosity of Frit 320 is low, 2) $\Delta G_{p}$ (limit for durability) is low, 3) waste loadings are high, and 4) removing $1 \% \mathrm{Na}_{2} \mathrm{O}$ from Frit 320 to compensate for the $1 \%$ addition of $\mathrm{MgO}$ causes the ratio of lithium to sodium in the frit to be higher.

For Frit 326 at $750^{\circ} \mathrm{C}$, bubbles began to form in the initial liquid phase along the sides and surface, but most of the batch was still unreacted. The greatest amount of foam arose at $800^{\circ} \mathrm{C}$, where medium-sized bubbles resided towards the top of the melt and smaller bubbles throughout. As evidenced by the figures, the samples were mostly glass at $850^{\circ} \mathrm{C}$ and $900^{\circ} \mathrm{C}$, with very few bubbles remaining.
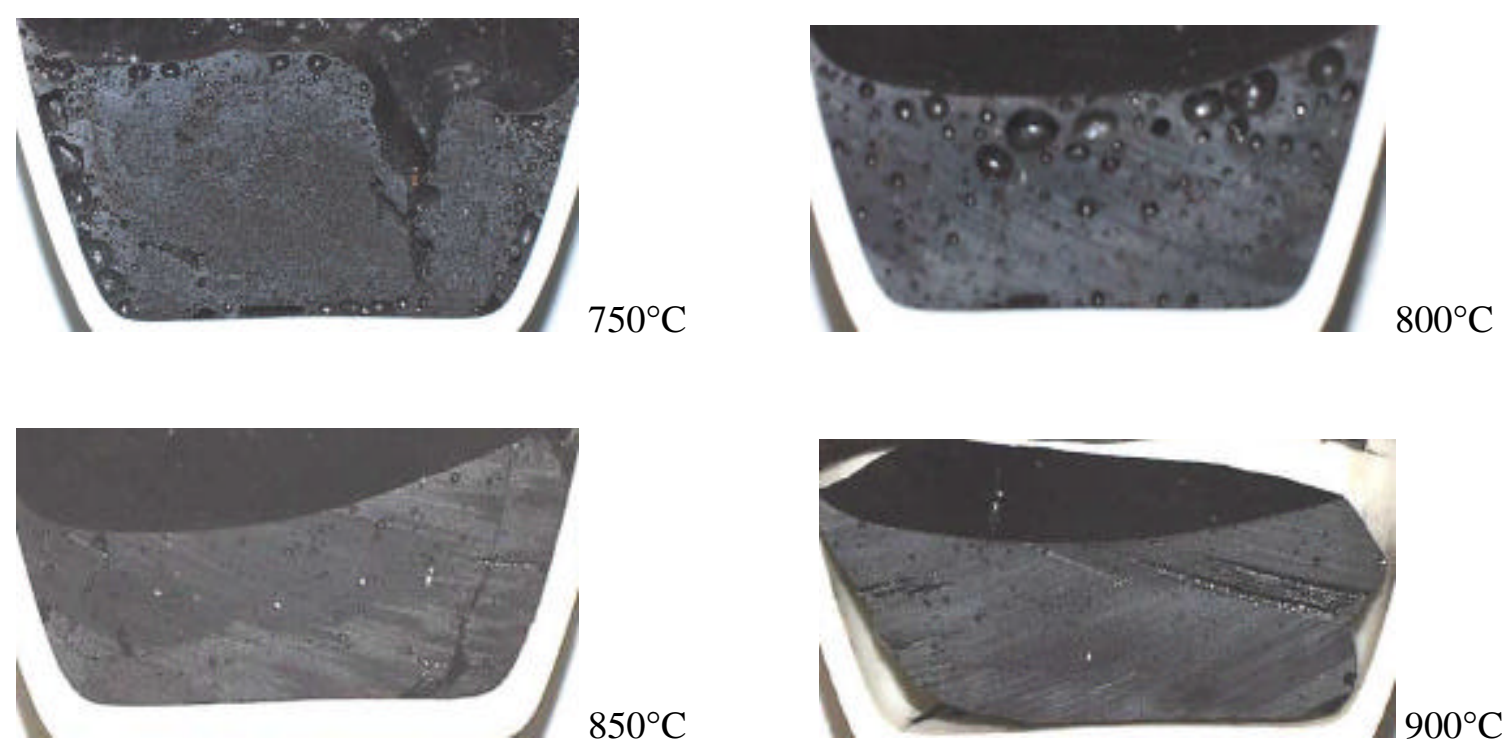

Figure 25. Frit 326 with MB3.

In comparing Frit 326 to 320 , the temperature where foam was the biggest problem was $800^{\circ} \mathrm{C}$ for each. However, it was not as dramatic for Frit 326 as it was for 320. Larger bubbles formed 
for Frit 320, and in a larger quantity. By this comparison, the presence of $\mathrm{MgO}$ may slightly enhance melt rate based on the crucible tests.

\subsection{Conclusions}

These crucible tests have been effective in giving a basic understanding of the melting behavior of MB3 over a series of frit compositions. The testing of 24 different frits has shown that there may be potential foaming issues with MB3, some worse than others. The problems can be alleviated though with the proper frit composition. This could minimize any bubbles or foam from being trapped during the melting process and slowing melt rate.

Several conclusions were made from the results of these crucible studies, which indicated the following:

1) The small-scale crucible studies are capable of distinguishing differences in the melting behavior of frits in testing of MB3.

2) Those frits that appeared to have the least foaming potential for MB3 and melted the fastest are Frits 313, 315, 323, 324, and 326.

3) Those frits that seemed to have foaming potential, but not extreme, were Frits 165, 200, 165 (75\% silica deficiency), 200 (75\% silica deficiency), 165 (batch chemicals), 200 (batch chemicals), 202, 303, 304, 307, 320, and 325.

4) Those frits with the most serious foaming potential appeared to be Frits 165 (25\% and $50 \%$ silica deficiency), 200 (25\% and 50\% silica deficiency), 165 without $\mathrm{ZrO}_{2}, 314$, and 322.

5) Melt rate can be enhanced via alteration of the frit composition, based on the crucible test.

6) Removal of $\mathrm{ZrO}_{2}$ from Frit 165, does not affect melt rate, based on the crucible tests.

7) The addition of 1 mass $\% \mathrm{MgO}$ at the expense of $\mathrm{Na}_{2} \mathrm{O}$ did not appear to affect melting behavior for Frit 326. If deemed necessary, 1 mass $\% \mathrm{MgO}$ could be added to meet other performance issues without negatively impacting melt rate, based on these crucible studies.

Again, these conclusions are based solely on results obtained from the crucible-scale tests and are highly subjective. Since there is no one "silver bullet" test that can ultimately produce all of the answers, further testing beyond these studies is required. 
WSRC-TR-2001-00126, Westinghouse Savannah River Company, Savannah River Technology Center, Aiken, SC.

Stone, M.E. and J.E. Josephs, 2001. "Melt Rate Improvements for MB3: Melt Rate Furnace Testing," WSRC-TR-2001-00146, Westinghouse Savannah River Company, Savannah River Technology Center, Aiken, SC.

GTOP-3-046, Rev. 4, Vitrification of Melter Feed Slurries for Reduction/Oxidation $\left(\mathrm{Fe}^{2+} / \Sigma \mathrm{Fe}\right)$ Measurement and/or Evaluation of Melter Materials of Construction, C.M. Jantzen, 1/17/01.

SRT-PTD-2000-00082, Macrobatch 3 SRAT Product Preparation for Melt Rate Tests: 15-Liter Batch (U), M.E. Stone, October 31, 2000.

SRT-PTD-2000-00088, Rev.1, Run Plan for Baseline Crucible Tests with Macrobatch 3 SRAT Product (U), M.E. Stone, November 8, 2000.

Technical Task Plan \# SR-1-6-WT-31, WSRC Immobilization. Subtask B. Waste loading improvements and high level waste glasses.

Technical Task Request \#HLW/DWPF/TTR-00-0044, DWPF Macrobatch 3 Melt Rate Study. Laboratory notebook \#WSRC-NB-2000-00144. 
Immobilization Technology Section

Savannah River Technology Center

Rev. 0

Westinghouse Savannah River Company

\section{Appendix}

Table III. Summarization of Crucible Tests of Frits 165, 200, and 303-326 with MB3.

Table IV. Foam Summarization of Frits 165, 200, and 303-326 with MB3. 
Table III. Summarization of Crucible Tests of Frits 165, 200, and 303-326 with MB3.

\begin{tabular}{|c|c|c|c|c|c|}
\hline Frit & $700^{\circ} \mathrm{C}$ & $750^{\circ} \mathrm{C}$ & $800^{\circ} \mathrm{C}$ & $850^{\circ} \mathrm{C}$ & $900^{\circ} \mathrm{C}$ \\
\hline 165 & Little melt & $\begin{array}{l}\text { Foam throughout (1-8 } \\
\text { mm diameter bubbles) }\end{array}$ & $\begin{array}{l}\text { Smaller residual } \\
\text { bubbles throughout } \\
(0.25-3 \mathrm{~mm} \text { diameter }) \\
\end{array}$ & Glass - dull on top & Glass - shiny on top \\
\hline 200 & $\begin{array}{l}\text { Little melt; few } \\
\text { bubbles beginning to } \\
\text { form }\end{array}$ & $\begin{array}{l}\text { Mostly small bubbles } \\
\text { throughout }(0.25-1 \\
\text { mm diameter); few } \\
\text { larger bubbles also (2- } \\
10 \text { mm diameter) }\end{array}$ & $\begin{array}{l}\text { Large bubbles } \\
\text { throughout (1-5 } \mathrm{mm} \\
\text { diameter) }\end{array}$ & $\begin{array}{l}\text { Residual bubbles } \\
\text { mostly at the top } \\
(0.25-2 \text { mm diameter })\end{array}$ & $\begin{array}{l}\text { Glass - shiny and } \\
\text { homogeneous on top }\end{array}$ \\
\hline 303 & Sintered & $\begin{array}{l}\text { Small bubbles } \\
\text { throughout }(0.5-2 \mathrm{~mm} \\
\text { diameter })\end{array}$ & $\begin{array}{l}\text { Many large bubbles } \\
\text { throughout (1-7 mm } \\
\text { diameter) }\end{array}$ & $\begin{array}{l}\text { Few residual bubbles } \\
\text { at top }(0.5-4 \mathrm{~mm} \\
\text { diameter) }\end{array}$ & $\begin{array}{l}\text { Glass (bubble free)- } \\
\text { dull and } \\
\text { homogeneous on top }\end{array}$ \\
\hline 304 & $\begin{array}{l}\text { Much foam } \\
\text { throughout (1-14 mm } \\
\text { diameter bubbles) }\end{array}$ & $\begin{array}{l}\text { Fewer and smaller } \\
\text { bubbles throughout } \\
(0.5-5 \mathrm{~mm} \text { diameter })\end{array}$ & $\begin{array}{l}\text { Small bubbles } \\
\text { throughout }(0.25-1 \\
\text { mm diameter) }\end{array}$ & Glass (bubble free) & Glass - shiny on top \\
\hline 307 & Sintered & Little to no melt & $\begin{array}{l}\text { Much foam } \\
\text { throughout }(0.25-9 \\
\text { mm diameter })\end{array}$ & $\begin{array}{l}\text { Few, small residual } \\
\text { bubbles at top }(0.25-1 \\
\text { mm diameter })\end{array}$ & $\begin{array}{l}\text { Glass - dull and } \\
\text { homogeneous on top }\end{array}$ \\
\hline 313 & Sintered & Little to no melt & $\begin{array}{l}\text { Still in initial melting } \\
\text { stage; very tiny } \\
\text { bubbles throughout } \\
(0.25 \mathrm{~mm} \text { diameter })\end{array}$ & $\begin{array}{l}\text { Few residual bubbles } \\
\text { at top }(0.25-4 \mathrm{~mm} \\
\text { diameter })\end{array}$ & Glass - shiny on top \\
\hline 314 & $\begin{array}{l}\text { Little melt (no } \\
\text { bubbles) }\end{array}$ & $\begin{array}{l}\text { Foam throughout } \\
(0.25-4 \mathrm{~mm} \text { diameter } \\
\text { bubbles })\end{array}$ & $\begin{array}{l}\text { Larger bubbles (foam } \\
\text { is worse) throughout } \\
\text { ( } 2-5 \mathrm{~mm} \text { diameter } \\
\text { bubbles) }\end{array}$ & $\begin{array}{l}\text { Fewer bubbles, but } \\
\text { mostly in top half of } \\
\text { melt (1-3 mm } \\
\text { diameter bubbles) }\end{array}$ & $\begin{array}{l}\text { Glass - dull and } \\
\text { homogeneous on top }\end{array}$ \\
\hline 315 & Sintered & $\begin{array}{l}\text { Little melt; initial } \\
\text { bubbles beginning to } \\
\text { form }\end{array}$ & $\begin{array}{l}\text { Very tiny bubbles } \\
\text { throughout; few larger } \\
\text { bubbles also ( } 2 \mathrm{~mm} \\
\text { diameter) }\end{array}$ & $\begin{array}{l}\text { Tiny bubbles } \\
\text { throughout; one large } \\
\text { bubble in middle of } \\
\text { melt }\end{array}$ & $\begin{array}{l}\text { Small residual } \\
\text { bubbles in top half or } \\
\text { glass }(0.5 \mathrm{~mm} \\
\text { diameter }) \text {; glass is }\end{array}$ \\
\hline
\end{tabular}




\begin{tabular}{|c|c|c|c|c|c|}
\hline & & & & & $\begin{array}{l}\text { dull and } \\
\text { homogeneous on top }\end{array}$ \\
\hline 320 & Little melt & $\begin{array}{l}\text { Tiny bubbles } \\
\text { beginning to form } \\
\text { throughout; larger } \\
\text { bubbles along the } \\
\text { sides }\end{array}$ & $\begin{array}{l}\text { Large bubbles } \\
\text { throughout (1-5 } \mathrm{mm} \\
\text { diameter) }\end{array}$ & $\begin{array}{l}\text { Few residual bubbles } \\
\text { (0.5 mm diameter) }\end{array}$ & $\begin{array}{l}\text { Glass - shiny and } \\
\text { homogeneous on top }\end{array}$ \\
\hline 322 & Sintered & $\begin{array}{l}\text { Many small bubbles } \\
\text { throughout }(0.25-3 \\
\text { mm diameter })\end{array}$ & $\begin{array}{l}\text { Small bubbles still } \\
\text { throughout, but not as } \\
\text { pronounced ( } 0.25-3 \\
\text { mm diameter) }\end{array}$ & $\begin{array}{l}\text { Very few residual } \\
\text { bubbles }(0.25-3 \mathrm{~mm} \\
\text { diameter })\end{array}$ & $\begin{array}{l}\text { Glass - dull and } \\
\text { homogeneous on top; } \\
\text { few residual bubbles } \\
\text { remain at top }\end{array}$ \\
\hline 323 & $\begin{array}{l}\text { Little melt (no } \\
\text { bubbles) }\end{array}$ & $\begin{array}{l}\text { Very tiny bubbles } \\
\text { throughout }(0.25-3 \\
\text { mm diameter })\end{array}$ & $\begin{array}{l}\text { Foam throughout } \\
(0.5-3 \mathrm{~mm} \text { diameter } \\
\text { bubbles })\end{array}$ & $\begin{array}{l}\text { Few residual bubbles } \\
\text { at top }\end{array}$ & $\begin{array}{l}\text { Glass - shiny and } \\
\text { homogeneous on top }\end{array}$ \\
\hline 324 & Sintered & Little to no melt & $\begin{array}{l}\text { Tiny bubbles } \\
\text { beginning to form at } \\
\text { top }(0.25 \mathrm{~mm} \\
\text { diameter })\end{array}$ & $\begin{array}{l}\text { Bubbles mostly in top } \\
\text { half of melt }(0.5-5 \\
\text { mm diameter })\end{array}$ & $\begin{array}{l}\text { Glass - dull and } \\
\text { homogeneous on top }\end{array}$ \\
\hline 325 & $\begin{array}{l}\text { Little melt (no } \\
\text { bubbles) }\end{array}$ & $\begin{array}{l}\text { Foam throughout } \\
(0.25-4 \text { mm diameter } \\
\text { bubbles })\end{array}$ & $\begin{array}{l}\text { Very tiny bubbles } \\
\text { throughout }(0.25-4 \\
\text { mm diameter }) \text {; one } \\
\text { large bubble in } \\
\text { middle ( } 13 \mathrm{~mm} \text { diam.) }\end{array}$ & $\begin{array}{l}\text { Very few residual } \\
\text { bubbles, but mostly at } \\
\text { top ( } 1-3 \mathrm{~mm} \\
\text { diameter) }\end{array}$ & $\begin{array}{l}\text { Glass - shiny and } \\
\text { homogeneous on top }\end{array}$ \\
\hline 326 & Sintered & $\begin{array}{l}\text { Onset of bubble } \\
\text { formation; larger } \\
\text { bubbles along sides }\end{array}$ & $\begin{array}{l}\text { Few larger bubbles, } \\
\text { but mostly at the top } \\
(0.5-4 \mathrm{~mm} \text { diameter })\end{array}$ & $\begin{array}{l}\text { Few residual bubbles } \\
\text { (0.5 mm diameter) }\end{array}$ & Glass - shiny on top \\
\hline
\end{tabular}


Table IV. Foam Summarization of Frits 165, 200, and 303-326 with MB3.

\begin{tabular}{|c|c|c|c|}
\hline Frit & $\begin{array}{c}\text { Temp. of } \\
\text { initial bubbles }\end{array}$ & $\begin{array}{c}\text { Temp. of } \\
\text { largest } \\
\text { bubbles } \\
\text { (worst foam) }\end{array}$ & $\begin{array}{c}\text { Temp. when } \\
\text { clear (bubble } \\
\text { free) }\end{array}$ \\
\hline 165 & $750^{\circ} \mathrm{C}$ & $750^{\circ} \mathrm{C}$ & $850^{\circ} \mathrm{C}$ \\
\hline 200 & $750^{\circ} \mathrm{C}$ & $800^{\circ} \mathrm{C}$ & $900^{\circ} \mathrm{C}$ \\
\hline \hline 303 & $750^{\circ} \mathrm{C}$ & $800^{\circ} \mathrm{C}$ & $900^{\circ} \mathrm{C}$ \\
\hline 304 & $700^{\circ} \mathrm{C}$ & $700^{\circ} \mathrm{C}$ & $850^{\circ} \mathrm{C}$ \\
\hline 307 & $800^{\circ} \mathrm{C}$ & $800^{\circ} \mathrm{C}$ & $850^{\circ} \mathrm{C}$ \\
\hline 313 & $800^{\circ} \mathrm{C}$ & $850^{\circ} \mathrm{C}$ & $900^{\circ} \mathrm{C}$ \\
\hline 314 & $750^{\circ} \mathrm{C}$ & $800^{\circ} \mathrm{C}$ & $900^{\circ} \mathrm{C}$ \\
\hline 315 & $750^{\circ} \mathrm{C}$ & $850^{\circ} \mathrm{C}$ & $900^{\circ} \mathrm{C}$ \\
\hline 320 & $750^{\circ} \mathrm{C}$ & $800^{\circ} \mathrm{C}$ & $900^{\circ} \mathrm{C}$ \\
\hline 322 & $750^{\circ} \mathrm{C}$ & $750^{\circ} \mathrm{C}$ & $850^{\circ} \mathrm{C}$ \\
\hline 323 & $750^{\circ} \mathrm{C}$ & $800^{\circ} \mathrm{C}$ & $900^{\circ} \mathrm{C}$ \\
\hline 324 & $800^{\circ} \mathrm{C}$ & $850^{\circ} \mathrm{C}$ & $900^{\circ} \mathrm{C}$ \\
\hline 325 & $750^{\circ} \mathrm{C}$ & $800^{\circ} \mathrm{C}$ & $900^{\circ} \mathrm{C}$ \\
\hline 326 & $750^{\circ} \mathrm{C}$ & $800^{\circ} \mathrm{C}$ & $900^{\circ} \mathrm{C}$ \\
\hline
\end{tabular}


Immobilization Technology Section

\section{Distribution}

L. M. Papouchado, 773-A

E. W. Holtzscheiter, 773-A

S. L. Marra, 704-1T

D. C. Witt, 704-1T

D. F. Bickford, 773-43A

D. K. Peeler, 773-43A

D. P. Lambert, 704-1T

T. H. Lorier, 773-23A

M. E. Stone, 704-1T

J. F. Ortaldo, 704-S

W. D. Kerley, 704-S

R. E. Edwards, 704-25S

M. R. Norton, 704-27S

J. E. Occhipinti, 704-27S

J. F. Sproull, 704-30S

D. C. Iverson, 704-30S

R. J. O'Driscoll, 704-30S

John Vienna, PNNL

Joe Perez, PNNL

Pavel Hrma, PNNL

STI, 703-43A (4) 